\title{
Indolizines Enabling Rapid Uncaging of Alcohols and Carboxylic Acids by Red Light-Induced Photooxidation
}

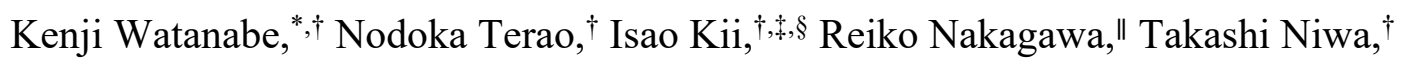 \\ and Takamitsu Hosoya ${ }^{*}, \dagger, \#$
}

\begin{abstract}
'Laboratory for Chemical Biology, RIKEN Center for Biosystems Dynamics Research (BDR), 6-7-3 Minatojimaminamimachi, Chuo-ku, Kobe 650-0047, Japan

*RIKEN Cluster for Science, Technology and Innovation Hub, 6-7-3 Minatojima-minamimachi, Chuo-ku, Kobe 6500047, Japan

${ }^{\S}$ Laboratory for Drug Target Research, Integrated Bioscience Division, Institute of Agriculture, Shinshu University, 8304 Minami-Minowa, Kami-Ina, Nagano, 399-4598, Japan

"Laboratory for Phyloinformatics, RIKEN Center for Biosystems Dynamics Research (BDR), 2-2-3 Minatojimaminamimachi, Chuo-ku, Kobe 650-0047, Japan

${ }^{\#}$ Laboratory of Chemical Bioscience, Institute of Biomaterials and Bioengineering, Tokyo Medical and Dental University (TMDU), 2-3-10 Kanda-Surugadai, Chiyoda-ku, Tokyo 101-0062, Japan
\end{abstract}

\section{Contents}

1. General S2

2. Chemicals S3

3. Screening of photosensitizers (Table S1) S4

4. Representative NMR spectra of photoreaction of indolizine 1 (Figure S1) S5

5. Treatment of $\mathbf{1 , 6}$, or $\mathbf{9}$ with excess hydrogen peroxide, acid, base, or serum (Figure S2) S6

$\begin{array}{ll}\text { 6. Kinetic studies (Figures S3 and S4) } & \text { S7-S8 }\end{array}$

7. Optimization of conditions for synthesis of 2-methoxyindolizine (S2) (Table S2) S9

8. Photoreaction of 9 in DMSO/serum (Figure S5) S10

9. Deconvoluted ESI-MS of peptides $\mathbf{1 3}$ and $\mathbf{1 6}$ (Figures S6 and S7) S11-S12

10. Stability of insulin-indolizine-4-MU conjugate $\mathbf{1 3}$ in serum in the presence $\begin{array}{ll}\text { or absence of glutathione (Figure S8) } & \text { S13 }\end{array}$

$\begin{array}{ll}\text { 11. Procedures for photoreactions and related reactions } & \text { S14-S17 }\end{array}$

$\begin{array}{ll}\text { 12. Synthetic procedures and characterization data } & \text { S18-S28 }\end{array}$

13. References for Supporting Information $\quad$ S29

$\begin{array}{ll}\text { 14. NMR spectra and HPLC chart } & \text { S30-S47 }\end{array}$ 


\section{General}

All reactions for synthesis of photoreactive substrates were performed under argon atmosphere and shading from light unless otherwise indicated. The definition for room temperature ( $\mathrm{rt}$ ) is $23-27^{\circ} \mathrm{C}$. An IKA RCT basic hot plate stirrer equipped with aluminum blocks was used for heating of 4 and $20 \mathrm{~mL}$ vials. Analytical thinlayer chromatography (TLC) was performed on precoated $(0.25 \mathrm{~mm})$ silica-gel plates (Merck, Merck Silica Gel 60 F254). Column chromatography was conducted on a YAMAZEN Automated Flash Chromatography System that consists of AI-580 and Parallel Frac FR-360 or a Biotage ISO-PSV Isolera Prime with a silicagel-packed column (Universal Premium Silica Gel $30 \mu \mathrm{m}$ or Biotage Sfär Silica HC D High Capacity Duo 20 $\mu \mathrm{m})$. Freeze drying was conducted with an EYELA FDS-2000. Melting points (mp) were measured with an OptiMelt automated melting point apparatus (Stanford Research Systems, Inc.) and were uncorrected. ${ }^{1} \mathrm{H}$ NMR (400 MHz) and ${ }^{13} \mathrm{C}$ NMR (100 MHz) spectra were obtained from measurements at room temperature on a JEOL ECS400 spectrometer. Chloroform- $d_{1}\left(\mathrm{CDCl}_{3}\right)$ containing $0.05 \%$ tetramethylsilane (TMS) $(99.8 \% \mathrm{D}$, Cambridge Isotope Laboratories, Inc.), methanol- $d_{4}\left(99.8 \% \mathrm{D}\right.$, Merck, Inc.), and dimethyl sulfoxide- $d_{6}$ (DMSO- $d_{6}, 99.9 \% \mathrm{D}$, Cambridge Isotope Laboratories, Inc.) were used as a solvent for NMR measurements. Chemical shifts $(\delta)$ for ${ }^{1} \mathrm{H}$ NMR are given in parts per million (ppm) downfield from signal of residual $\mathrm{CHCl}_{3}$ ( $\delta 7.26 \mathrm{ppm})$, methanol $(\delta 3.31 \mathrm{ppm})$, and dimethyl sulfoxide $(\delta 2.50 \mathrm{ppm})$ as internal standards with coupling constants $(J)$ in hertz $(\mathrm{Hz})$. Chemical shifts $(\delta)$ for ${ }^{13} \mathrm{C}$ NMR are given in parts per million (ppm) downfield from signal of residual $\mathrm{CDCl}_{3}(\delta 77.2 \mathrm{ppm})$ and dimethylsulfoxide- $d_{6}(\delta 39.5 \mathrm{ppm})$ as internal standards. The abbreviations $\mathrm{s}, \mathrm{d}, \mathrm{t}, \mathrm{q}$, and $\mathrm{m}$ signify singlet, doublet, triplet, quartet, and multiplet, respectively. IR spectra were measured by attenuated total reflection method on a Shimadzu IRPrestige- 21 spectrometer with the absorption band given in $\mathrm{cm}^{-1}$. Fluorescence spectra were recorded on a JASCO FP-6600 spectrofluorometer. High performance liquid chromatography was performed on Shimadzu HPLC Systems that consists of LC20AB (liquid chromatograph), DGU-20A3 (degasser), SPD-M20A (diode array detector), SIL-20A (auto sampler), CTO-20AC (column oven), and CBM-20A (communication bus) or LC-20AR (liquid chromatograph), DGU-20A5R (degasser), SPD-M20A (diode array detector), FRC-40 (fraction collector), and CBM-20A (communications bus) units. Recycle gel permeation chromatography (GPC) was performed on a YMC LC-Forte/R multiple preparative HPLC system. High-resolution mass spectra (HRMS) were measured on a Thermo Fisher Scientific Exactive Plus Orbitrap mass spectrometer or a Thermo Fisher Scientific Q Exactive Orbitrap mass spectrometer equipped with a DIONEX Ultimate 3000 ultra performance liquid chromatography (UPLC) system. Deconvolution of mass spectrum was performed by using a Xcaliber Free Style $^{\mathrm{TM}} 1.1 \mathrm{SP} 1$ software. 


\section{Chemicals}

Tetrahydrofuran (THF, deoxygenated), $N, N$-dimethylformamide (DMF, deoxygenated), isopropyl alcohol ( $i$ - $\mathrm{PrOH}$, deoxygenated), dichloromethane $\left(\mathrm{CH}_{2} \mathrm{Cl}_{2}\right.$, deoxygenated), chloroform (deoxygenated), methanol (deoxygenated), ultrapure water, hydrochloric acid $(1 \mathrm{M})$, and aqueous hydrogen peroxide (30-35.5 v/v \%) were purchased from FUJIFILM Wako Pure Chemical. Ethyl acetate (EtOAc), $n$-hexane, ethanol (EtOH), tertbutyl alcohol ( $t$-BuOH), 1,2-dimethoxyethane (DME), dimethyl sulfoxide (DMSO), acetonitrile (HPLC grade), potassium hydrogen carbonate $\left(\mathrm{KHCO}_{3}\right)$, potassium carbonate $\left(\mathrm{K}_{2} \mathrm{CO}_{3}\right)$, tripotassium phosphate $\left(\mathrm{K}_{3} \mathrm{PO}_{4}\right)$, sodium hydroxide $(\mathrm{NaOH})$, sodium carbonate $\left(\mathrm{Na}_{2} \mathrm{CO}_{3}\right)$, sodium tert-butoxide $(t-\mathrm{BuONa})$, ethyl bromoacetate, cesium hydroxide monohydrate $\left(\mathrm{CsOH} \cdot \mathrm{H}_{2} \mathrm{O}\right)$, cesium carbonate $\left(\mathrm{Cs}_{2} \mathrm{CO}_{3}\right)$, cesium phosphate $\left(\mathrm{Cs}_{3} \mathrm{PO}_{4}\right)$, sodium sulfate $\left(\mathrm{Na}_{2} \mathrm{SO}_{4}\right)$, sodium hydrogen carbonate $\left(\mathrm{NaHCO}_{3}\right)$, phenyl chloroformate, benzyl chloroformate, benzoyl chloride, thionyl chloride, oxalyl chloride, 4-methylumbelliferone (4-MU), potassium tert-butoxide ( $t$-BuOK), ammonium formate $\left(\mathrm{NH}_{4} \mathrm{HCO}_{3}\right)$, ammonium carbonate $\left(\left(\mathrm{NH}_{4}\right)_{2} \mathrm{CO}_{3}\right)$, phosphoric acid, copper(II) sulfate pentahydrate, sodium L-ascorbate, 1-naphthol, trifluoroacetic acid, fluorescein, rhodamine B, phthalocyanine, and glutathione were purchased from Nacalai Tesque. 2-Methylpyridine, dimethyl sulfate $\left(\left(\mathrm{CH}_{3}\right)_{2} \mathrm{SO}_{4}\right), 3$-phenylpropionic acid, bexarotene, ethyl propiolate, 1-phenylpiperazine, tris((1-benzyl-1H1,2,3-triazol-4-yl)methyl)amine (TBTA), phenol (PhOH), benzyl alcohol (BnOH), 5-carboxyfluorescein, rose bengal, methylene blue, benzoic acid, and 3-phenylpropanoic acid were purchased from Tokyo Chemical Industry. 4-Nitrophenyl chloroformate, 9-mesityl-10-methylacridinium perchlorate, 6-bromo-4hydroxycoumarin, and silicon phthalocyanine dichloride were purchased from Sigma-Aldrich. Tris(2,2'bipyridyl)ruthenium(II) chloride hexahydrate $\left(\mathrm{Ru}(\mathrm{II})(\mathrm{bpy})_{3} \mathrm{Cl}_{2}\right)$ was purchased from Alfa Aeser. Phthalocyanine tetrasulfonic acid was purchased from Frontier Scientific. 3-(4-Methyl-1,4epidioxynaphthalen-1(4H)-yl)propanoic acid (2) was purchased from WakenBtech. All reagents purchased were used as received. 2-Methyl-5-(prop-2-yn-1-yloxy)pyridine, ${ }^{\mathrm{S} 1}$ 2-methylindolizine ${ }^{\mathrm{S} 2}$, 4-methyl-2-oxo- $2 \mathrm{H}$ chromen-7-yl carbonochloridate, ${ }^{\mathrm{S} 3}$ triazidoinsulin (14), ${ }^{\mathrm{S} 4}$ and 4-phenylpiperazine-1-carbaldehyde $(\mathbf{P 1})^{\mathrm{S} 5}$ were synthesized according to the literature. 
3. Screening of photosensitizers (Table S1)

\begin{tabular}{|c|c|c|c|c|c|}
\hline & $=0$ & $\begin{array}{c}660 \mathrm{~nm} \text { LED } \\
\mathrm{PS}(1-2 \mathrm{~mol} \%) \\
t-\mathrm{BuOH}(1 \text { equiv) }\end{array}$ & & & \\
\hline entry & photosensitizer (PS) & $\lambda_{\max }(\mathrm{nm})^{a}$ & $\mathrm{~mol} \mathrm{\%}$ & time (sec) & yield $(\%)^{b}$ \\
\hline 1 & fluorescein & 479 & 2 & 180 & $<5$ \\
\hline 2 & 5-carboxyfluorescein & 459 & 2 & 180 & $<5$ \\
\hline 3 & rhodamine B & 546 & 2 & 180 & $<5$ \\
\hline 4 & rose bengal & 557 & 2 & 180 & 21 \\
\hline 5 & 9-mesityl-10-methylacridinium perchlorate & 360 & 2 & 180 & $<5$ \\
\hline 6 & 6-bromo-4-hydroxycoumarin & 309 & 2 & 180 & $<5$ \\
\hline 7 & methylene blue & 653 & 2 & 180 & $>95$ \\
\hline 8 & phthalocyanine & 622 & 2 & 180 & $<5$ \\
\hline 9 & $\mathrm{Ru}(\mathrm{II})(\mathrm{bpy})_{3} \mathrm{Cl}_{2}$ & 450 & 2 & 180 & 21 \\
\hline 10 & phthalocyanine tetrasulfonic acid & 683 & 2 & 180 & 68 \\
\hline 11 & silicon phthalocyanine dichloride & 671 & 2 & 180 & 68 \\
\hline 12 & methylene blue & 653 & 1 & 30 & $>95$ \\
\hline
\end{tabular}

${ }^{a}$ Maximum absorption wavelength $\left(\lambda_{\max }\right)$ in methanol. ${ }^{b}$ Yields determined by ${ }^{1} \mathrm{H}$ NMR measurement. 
4. Representative NMR spectra of photoreaction of indolizine 1 (Figure S1)
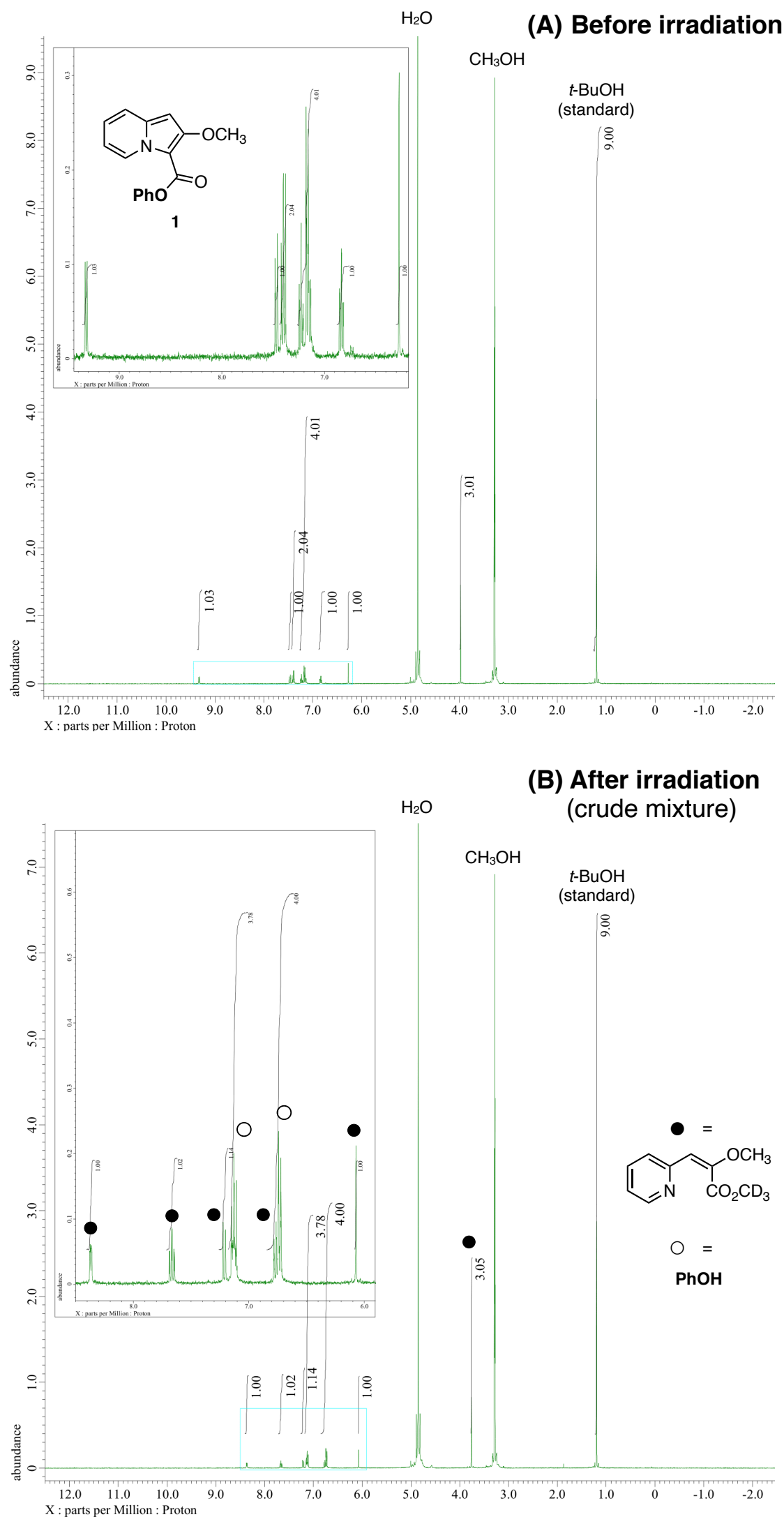

Figure S1. NMR spectra of a reaction mixture before (A) and after (B) the photoreaction of indolizine 1 used for determining the reaction yield in Table S1, entry 12. Conditions: $1(2.0 \mathrm{mM})$, methylene blue (20 $\mu \mathrm{M}, 1.0 \mathrm{~mol} \%)$, methanol- $d_{4}(0.7 \mathrm{~mL}), 660 \mathrm{~nm}$ LED irradiation, rt, $30 \mathrm{sec}$. 
5. Treatment of 1, 6, or 9 with excess hydrogen peroxide, acid, base, or serum (Figure S2)

(A)

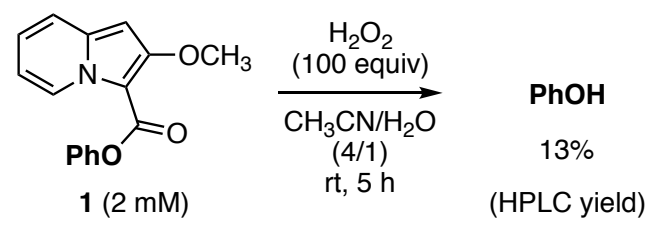

(B)

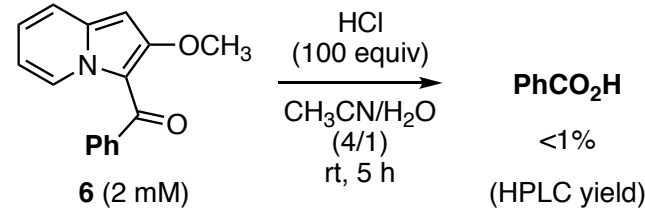

(C)

(D)
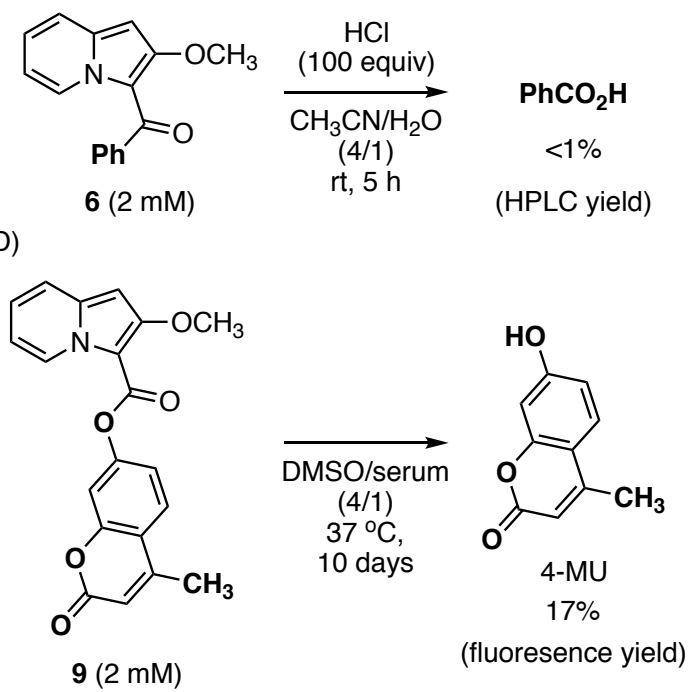

Figure S2. Treatment of 1, 6, or 9 with excess hydrogen peroxide, acid, base, or serum. Conditions: 1, 6, or 9 (2.0 mM, for A-D), $\mathrm{H}_{2} \mathrm{O}_{2}$ (200 mM, 100 equiv, for A), $\mathrm{HCl}$ (200 mM, 100 equiv, for B), $\mathrm{NaOH}(200 \mathrm{mM}$, 100 equiv, for $\mathrm{C}$ ) in $\mathrm{CH}_{3} \mathrm{CN} / \mathrm{H}_{2} \mathrm{O}(4 / 1,0.5 \mathrm{~mL}$, for $\mathrm{A}-\mathrm{C}), \mathrm{DMSO} / \mathrm{serum}(4 / 1,0.5 \mathrm{~mL}$, for $\mathrm{D})$. 

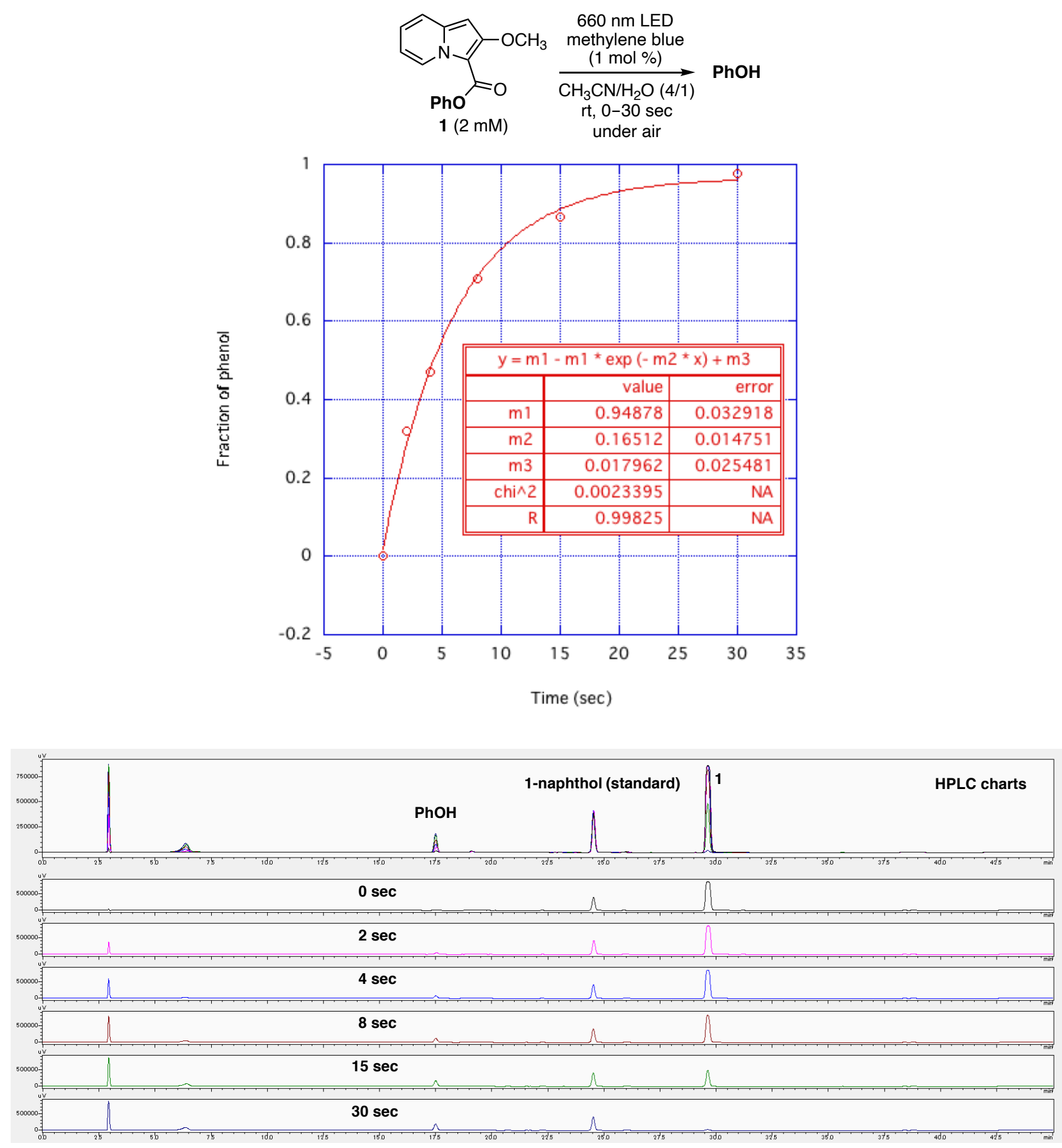

Figure S3. Representative result for time-dependent changes of the amount of phenol released from compound 1 by photoirradiation. Conditions: $1(2.0 \mathrm{mM})$, methylene blue $(20 \mu \mathrm{M}, 1.0 \mathrm{~mol} \%), \mathrm{CH}_{3} \mathrm{CN} / \mathrm{H}_{2} \mathrm{O}$ (4/1, $0.5 \mathrm{~mL}), 660 \mathrm{~nm}$ LED irradiation, rt, $0-30 \mathrm{sec}$. The amount of phenol was measured by HPLC analysis. The curve fitting was performed by using pseudo first-order rate equation: $\mathrm{y}=\mathrm{m} 1-\mathrm{m} 1 * \exp (-\mathrm{m} 2 * \mathrm{x})+\mathrm{m} 3$, where $\mathrm{x}, \mathrm{y}, \mathrm{m} 1, \mathrm{~m} 2$, and $\mathrm{m} 3$ stand for time $(t)$, fraction of phenol at $t$, increase of fraction of phenol from $t_{0}$ to $t_{\max }$, apparent rate constant $\left(k_{\mathrm{obs}}\right)$, and fraction of phenol at $t_{0}$, respectively.

$k_{\text {obs }}\left(\mathrm{s}^{-1}\right)=0.149 \pm 0.017\left(0.125\left(1^{\text {st }}\right), 0.155\left(2^{\text {nd }}\right), 0.165\left(3^{\text {rd }}\right)\right)$ 

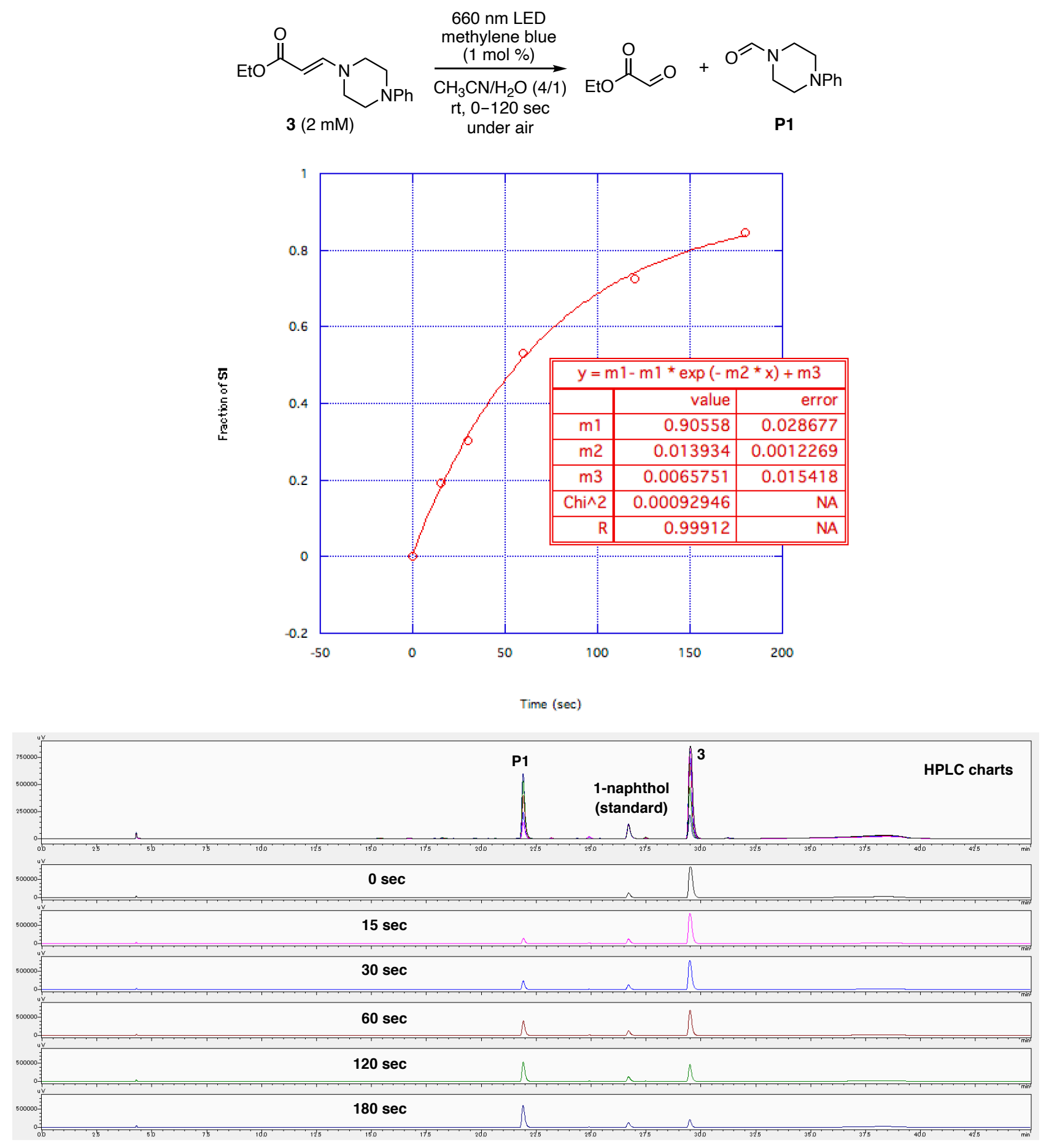

Figure S4. Representative result for time-dependent changes of the amount of P1 released from compound 3 by photoirradiation. Conditions: $3(2.0 \mathrm{mM})$, methylene blue $(20 \mu \mathrm{M}, 1.0 \mathrm{~mol} \%), \mathrm{CH}_{3} \mathrm{CN} / \mathrm{H}_{2} \mathrm{O}$ (4/1, $0.5 \mathrm{~mL}), 660 \mathrm{~nm}$ LED irradiation, $\mathrm{rt}, 0-120 \mathrm{sec}$. The amount of $\mathbf{P} 1$ was measured by HPLC analysis. The curve fitting was performed by using pseudo first-order rate equation: $\mathrm{y}=\mathrm{m} 1-\mathrm{m} 1 * \exp (-\mathrm{m} 2 * \mathrm{x})+\mathrm{m} 3$, where $\mathrm{x}, \mathrm{y}, \mathrm{m} 1, \mathrm{~m} 2$, and $\mathrm{m} 3$ stand for time $(t)$, fraction of $\mathbf{P} 1$ at $t$, increase of fraction of $\mathbf{P} 1$ from $t_{0}$ to $t_{\max }$, apparent rate constant $\left(k_{\mathrm{obs}}\right)$, and fraction of $\mathbf{P 1}$ at $t_{0}$, respectively.

$k_{\text {obs }}\left(\mathrm{s}^{-1}\right)=0.0138 \pm 0.0013\left(0.0124\left(1^{\mathrm{st}}\right), 0.0134\left(2^{\text {nd }}\right), 0.0156\left(3^{\text {rd }}\right), 0.0139\left(4^{\text {th }}\right)\right)$ 


\section{Optimization of conditions for synthesis of 2-methoxyindolizine (S2) (Table S2)}

The previously reported conditions for the preparation of 2-alkoxyindolizines via intramolecular cyclization of pyridinium salt $\mathbf{S 1}$ was not practical, as it led the generation of inseparable byproduct $\mathbf{S 3}$ (Table S2, entry 1). ${ }^{\mathrm{S} 6}$ We reoptimized the reaction conditions and found that the use of cesium hydroxide as a base suppressed the formation of $\mathbf{S 3}$, affording $\mathbf{S} \mathbf{2}$ in pure form after a typical column chromatography purification procedure using a silica-gel-packed column (Biotage Sfär Silica HC D High Capacity Duo $20 \mu \mathrm{m}$ ).

\begin{tabular}{|c|c|c|c|c|c|}
\hline & & 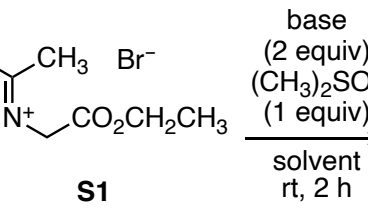 & s2 & S3 & \\
\hline entry & base & solvent & yield of $\mathbf{S 2}(\%)^{a}$ & yield of $\mathbf{S 3}(\%)^{a}$ & ratio $\mathbf{S 2} / \mathbf{S 3}$ \\
\hline 1 & $t$-BuOK & $\mathrm{EtOH}$ & \multicolumn{2}{|c|}{$10{\text { (mixture })^{b}}^{b}$} & - \\
\hline 2 & $t$-BuOK & $i-\mathrm{PrOH}$ & 27 & 4 & 6.8 \\
\hline 3 & $t$-BuOK & $t-\mathrm{BuOH}$ & 10 & 6 & 1.7 \\
\hline 4 & $t$-BuOK & THF & 10 & 4 & 2.5 \\
\hline 5 & $t$-BuOK & 1,4-dioxane & 2 & 0 & - \\
\hline 6 & $t$-BuOK & DME & 0 & 0 & - \\
\hline 7 & $\mathrm{KHCO}_{3}$ & $i-\mathrm{PrOH}$ & 0 & 0 & - \\
\hline 8 & $\mathrm{~K}_{2} \mathrm{CO}_{3}$ & $i-\mathrm{PrOH}$ & 0 & 0 & - \\
\hline 9 & $\mathrm{~K}_{3} \mathrm{PO}_{4}$ & $i-\mathrm{PrOH}$ & 3 & 0 & - \\
\hline 10 & $\mathrm{Na}_{2} \mathrm{CO}_{3}$ & $i-\mathrm{PrOH}$ & 0 & 0 & - \\
\hline 11 & $t$-BuONa & $i-\mathrm{PrOH}$ & 0 & 0 & - \\
\hline 12 & $\mathrm{Cs}_{2} \mathrm{CO}_{3}$ & $i-\mathrm{PrOH}$ & 10 & 3 & 3.3 \\
\hline 13 & $\mathrm{Cs}_{3} \mathrm{PO}_{4}$ & $i-\mathrm{PrOH}$ & 0 & 0 & - \\
\hline 14 & $\mathrm{CsOH} \cdot \mathrm{H}_{2} \mathrm{O}$ & $i-\mathrm{PrOH}$ & 32 & 4 & 8 \\
\hline 15 & $\mathrm{CsOH} \cdot \mathrm{H}_{2} \mathrm{O}$ & $\mathrm{EtOH}$ & 9 & 2 & 4.5 \\
\hline 16 & $\mathrm{CsOH} \cdot \mathrm{H}_{2} \mathrm{O}$ & $i-\mathrm{PrOH}$ & 32 & 4 & 8 \\
\hline 17 & $\mathrm{CsOH} \cdot \mathrm{H}_{2} \mathrm{O}$ & $t-\mathrm{BuOH}$ & 0 & 0 & - \\
\hline 18 & $\mathrm{CsOH} \cdot \mathrm{H}_{2} \mathrm{O}$ & THF & 7 & 4 & 1.8 \\
\hline 19 & $\mathrm{CsOH} \cdot \mathrm{H}_{2} \mathrm{O}$ & 1,4-dioxane & 12 & 5 & 2.4 \\
\hline 20 & $\mathrm{CsOH} \cdot \mathrm{H}_{2} \mathrm{O}$ & DME & 4 & 1 & 4 \\
\hline 21 & $\mathrm{CsOH} \cdot \mathrm{H}_{2} \mathrm{O}$ & DMF & 12 & 0 & - \\
\hline 22 & $\mathrm{CsOH} \cdot \mathrm{H}_{2} \mathrm{O}$ & $i$-PrOH/DMF (1/1) & $25(27)^{c}$ & 1 & 27 \\
\hline
\end{tabular}

${ }^{a}$ Yields determined by ${ }^{1} \mathrm{H}$ NMR measurement, unless otherwise noted.

${ }^{b}$ Yield reported in literature (ref S6).

${ }^{c}$ Isolated yield shown in parentheses. 


\section{Photoreaction of 9 in DMSO/serum (Figure S5)}

(A)
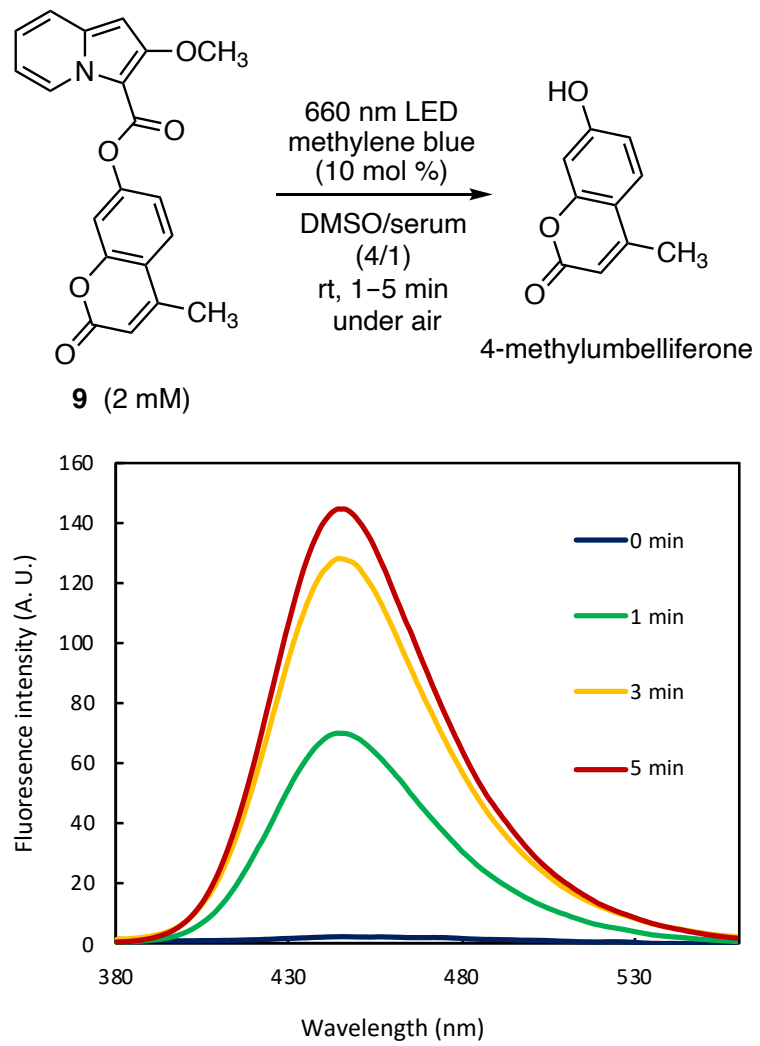

(B)

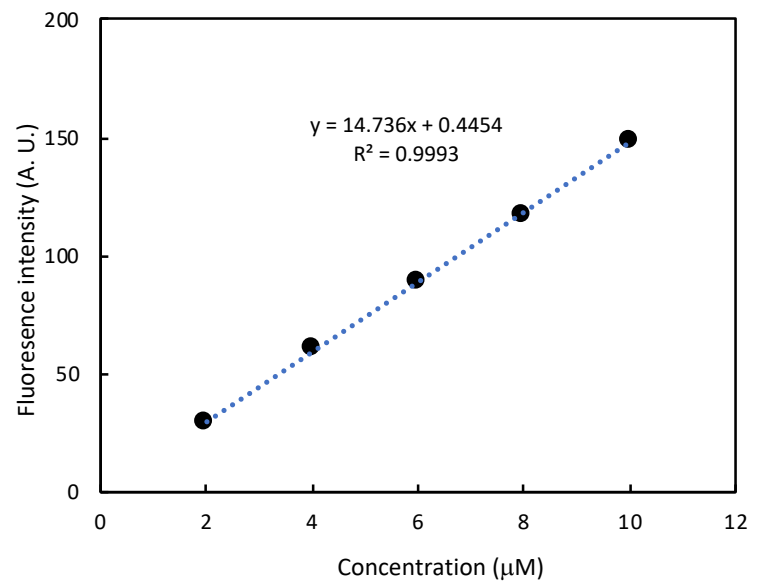

Figure S5. Photoreaction of compound 9 in DMSO/serum. (A) Fluorescence increase upon release of 4methylumbellifenone (4-MU) from 9 by photoirradiation in DMSO/serum (4/1) (B) Calibration curve to determine the amount of 4-MU $\left(\lambda_{\text {ex }}=360 \mathrm{~nm}, \lambda_{\text {em }}=446 \mathrm{~nm}\right)$. Yields: $1 \mathrm{~min}, 47 \% ; 3 \mathrm{~min}, 86 \% ; 5 \mathrm{~min}, 98 \%$. 
9. Deconvoluted ESI-MS of peptides 13 and 16 (Figures S6 and S7)
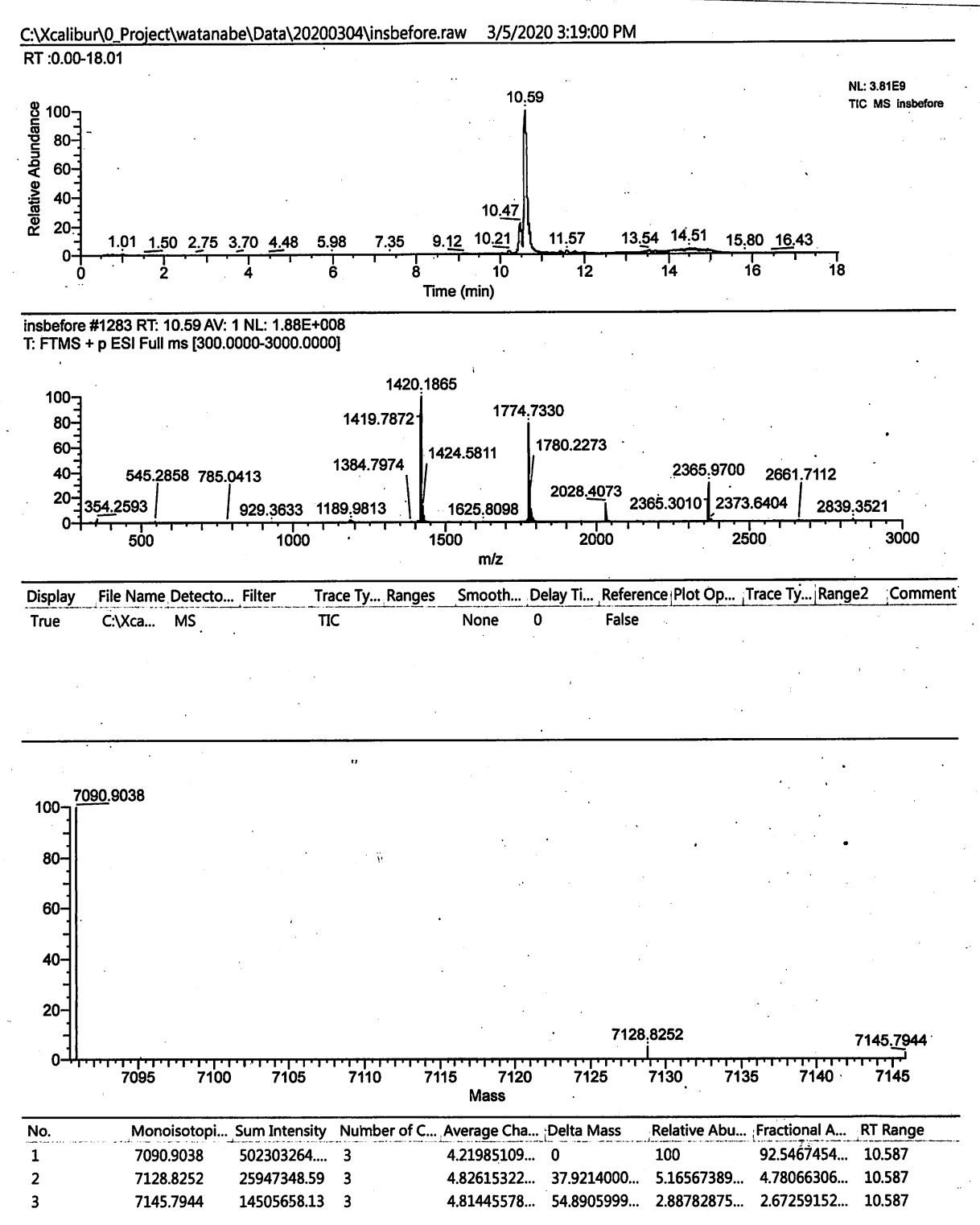

Figure S6. Deconvoluted ESI-MS of conjugate 13. Observed, 7090.9038; Calculated, 7090.9259, Difference, 0.0221 (3.12 ppm). ESI-Deconvolution of mass spectrum was performed by using a Xcaliber Free Style ${ }^{\mathrm{TM}} 1.1$ SP1 software. 


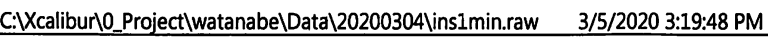

RT :0.00-18.02

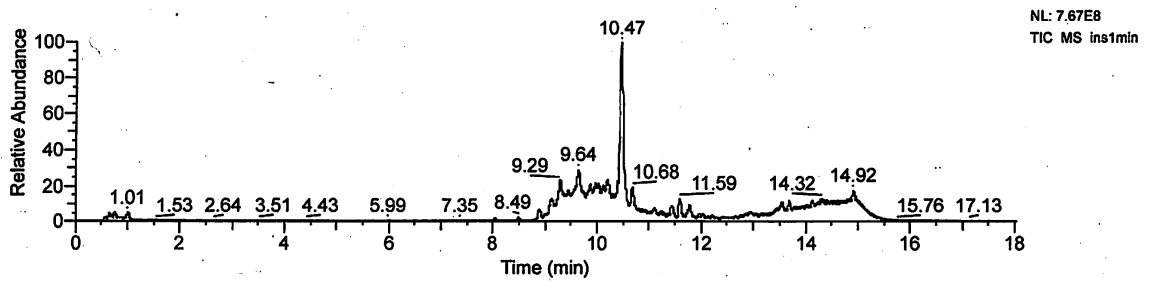

ins1min \#1057 RT: $8.91 \mathrm{AV}: 1 \mathrm{NL}: 1.23 \mathrm{E}+006$

T: FTMS + p ESI Full ms [300.0000-3000.0000]

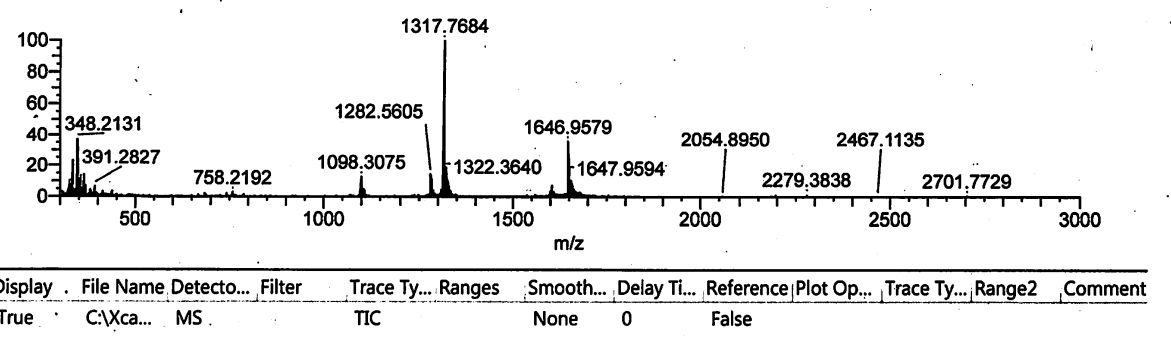

True C:X $\mathrm{Xca...}$ MS $\mathrm{MC}$ None 0 False

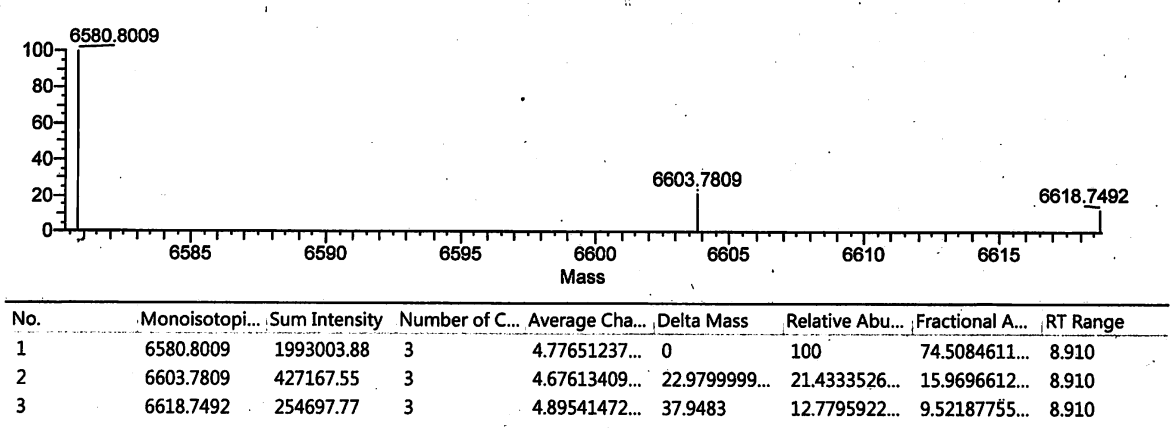

Figure S7. Deconvoluted ESI-MS of peptide 16. Observed, 6580.8009; Calculated, 6580.8156, Difference, $0.0147(2.23 \mathrm{ppm})$. ESI-Deconvolution of mass spectrum was performed by using a Xcaliber Free Style ${ }^{\mathrm{TM}} 1.1$ SP1 software. 
10. Stability of insulin-indolizine-4-MU conjugate 13 in serum in the presence or absence of glutathione (Figure S8)

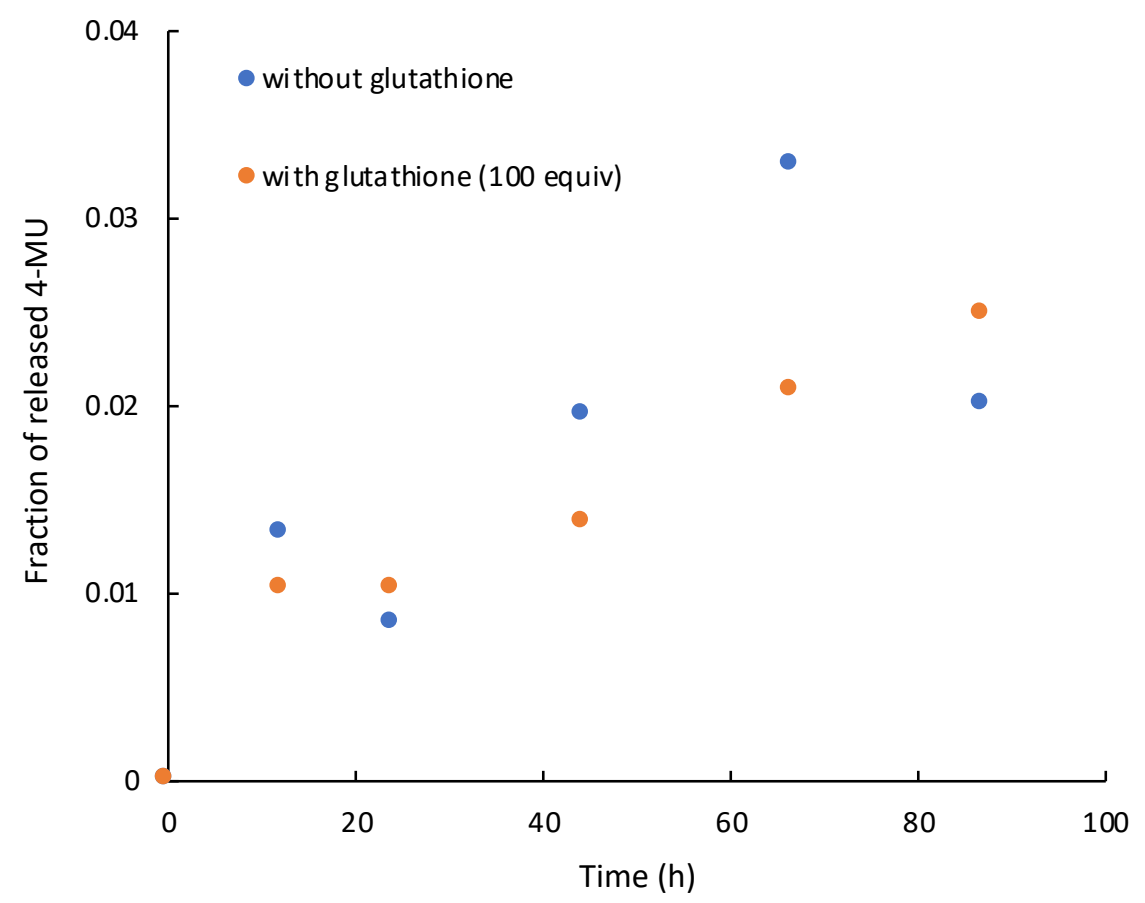

Figure S8. Time-dependent release of 4-methylumbellifenone (4-MU) from insulin-indolizine-4-MU conjugate 13 in serum in the presence or absence of glutathione. A solution of conjugate $13(20 \mu \mathrm{M})$ in serum/DMSO (98/2) in the absence (A) or presence of glutathione (B, $2.0 \mathrm{mM}, 100$ equiv) was incubated at $37^{\circ} \mathrm{C}$ under darkness and the released 4-MU was monitored for $0-87 \mathrm{~h}$. 


\section{Procedures for photoreactions and related reactions}

All photoreactions were performed in a vial placed in PhotoRedOx Box (EvoluChem) equipped with a Kessil H160 Tuna Flora LED lamp (40 W, maximum irradiation of a red channel) as a light source. The experimental setup for photoreactions and wavelength spectrum of the LED lamp is shown in Figure S9.

(A)
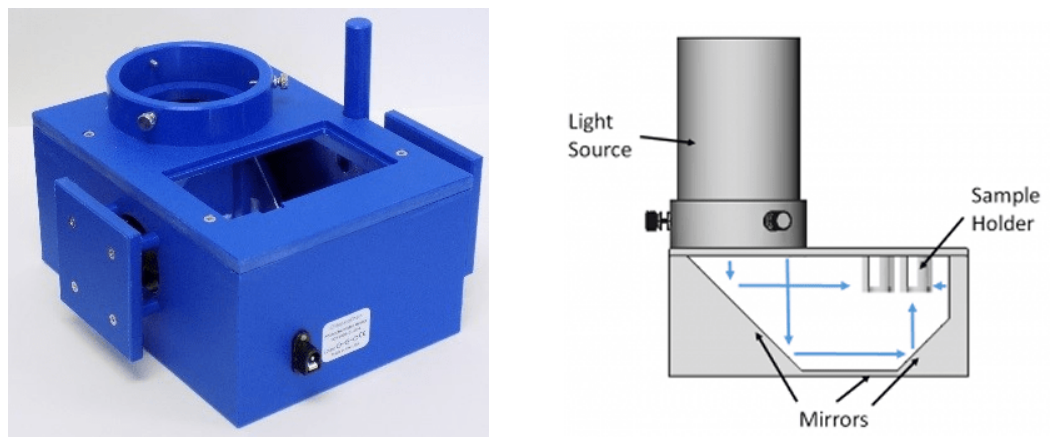

(B)

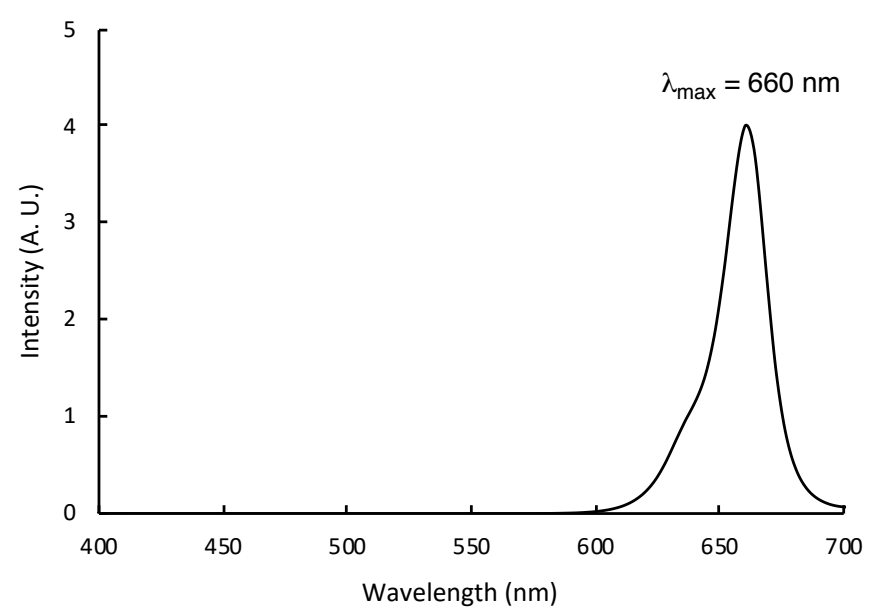

Figure S9. (A) Experimental setup for photoreactions (pictures from homepage of EvoluChem: https://www.hepatochem.com/photoreactors-leds-accessories/photoredox-box/).

(B) Wavelength spectrum of a Kessil H160 Tuna Flora LED lamp measured by a Konica Minolta CL-500A illuminometer equipped with an Opto Sigma AND-25C-01 filter (1\% transmittance at 400-700 nm). 


\section{Detailed procedures for photoreactions and related reactions}

i) Screening of photosensitizer (Table S1, Figure S1)

To a solution of compound $\mathbf{1}(2.0 \mathrm{mM})$ and tert-butyl alcohol $(2.0 \mathrm{mM})$ in methanol- $d_{4}(700 \mu \mathrm{L})$ in a $4 \mathrm{~mL}$ vial were added a solution of photosensitizer in methanol- $d_{4}(2.5 \mathrm{mM}, 5.6-11.2 \mu \mathrm{L}, 1.0-2.0 \mathrm{~mol} \%)$ and a magnetic stir bar under air. The solution was vigorously stirred by a magnetic stirrer at room temperature and photoirradiated for 30-180 sec. After the irradiation, the solution was transferred to an NMR tube, and ${ }^{1} \mathrm{H}$ NMR measurement was performed. The reaction yields (\%) of phenol were determined by comparison of the integral values of the peaks corresponding to phenol and that of tert-butyl alcohol as an internal standard.

ii) Photoreaction of 1 under $1 \% \mathrm{O}_{2}$ and argon atmosphere (Figure $2 \mathrm{~A}$ )

Stock solutions of 1 ( $2.0 \mathrm{mM}, 5.0 \mathrm{~mL}, 1$ equiv), tert-butyl alcohol ( $0.20 \mathrm{M}, 50 \mu \mathrm{L}, 1.0$ equiv), and methylene blue ( $4.0 \mathrm{mM}, 25 \mu \mathrm{L}, 1.0 \mathrm{~mol} \%$ ) in methanol- $d_{4}$, which were preliminary purged with $0.9947 \% \mathrm{O}_{2} / \operatorname{argon}$ gas or $99.999 \%$ argon gas (Koatsu Gas Kogyo) for $20 \mathrm{~min}$, were combined into a $20 \mathrm{~mL}$ vial equipped with a septum cap, filled with the gas. The resulting solution of $\mathbf{1}$ containing methylene blue and tert-butyl alcohol was further purged with the gas for $5 \mathrm{~min}$. A part of the purged solution of $\mathbf{1}(700 \mu \mathrm{L})$ was transferred into another $4 \mathrm{~mL}$ vial equipped with a septum cap and magnetic stir bar and filled with the gas using a gas tight syringe. The resultant solution was vigorously stirred by a magnetic stirrer at room temperature and photoirradiated for $30 \mathrm{sec}$. After the irradiation, the solution was transferred to an NMR tube, and ${ }^{1} \mathrm{H}$ NMR measurement was performed. The reaction yields (\%) of phenol were determined by comparison of the integral values of the peaks corresponding to phenol and that of tert-butyl alcohol as an internal standard.

iii) Substrate scope (Table 1) and kinetic study (Figures S3 and S4)

To a solution of the substrate in acetonitrile $(2.5 \mathrm{mM}, 400 \mu \mathrm{L})$ in a $4 \mathrm{~mL}$ vial were added ultrapure water $(100 \mu \mathrm{L})$, an aqueous solution of methylene blue $(1.25 \mathrm{mM}, 8.0 \mu \mathrm{L}, 1.0 \mathrm{~mol} \%)$, and a magnetic stir bar under air. The solution was vigorously stirred by a magnetic stirrer at room temperature and photoirradiated for 0 $60 \mathrm{sec}$. After the photoirradiation, a solution of 1-naphthol $(4.0 \mathrm{mM})$ in acetonitrile $(250 \mu \mathrm{L})$ was added, and a portion of the resulting solution was subjected to HPLC analysis. The reaction yields (\%) were determined by comparison of the peak area of the product (phenol for $\mathbf{1}$ and 10-12; 4-phenylpiperazine-1-carbaldehyde (P1) for 3; benzyl alcohol for 4; benzoic acid for 6; 3-phenylpropanoic acid for 7; bexarotene for 8; 4 methylumbellifenone for 9) or the starting material (3) and that of 1-naphthol as an internal standard. The peak areas of the products were calibrated against that of the standard (1-naphthol, $\mathrm{R}^{2}>0.99$ ). The conditions for HPLC analysis are as below:

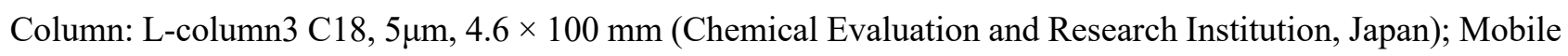
phase: $\mathbf{A}=$ acetonitrile, $\mathbf{B}=$ aqueous $\mathrm{NH}_{4} \mathrm{HCO}_{2}(40 \mathrm{mM}), \mathbf{C}=$ aqueous $\mathrm{H}_{3} \mathrm{PO}_{4}(40 \mathrm{mM})$, $\mathbf{D}$ : aqueous $\left(\mathrm{NH}_{4}\right)_{2} \mathrm{CO}_{3}$ (20 mM); Gradient method: For 1, 4, 9, 10-12: $\mathbf{A} / \mathbf{B}=5 / 95$ to $95 / 5(0-30 \mathrm{~min})$; For 6-8: $\mathbf{A} / \mathbf{C}=5 / 95$ to $95 / 5$ (0-30 $\mathrm{min})$; For 3: A/D = 5/95 to 95/5 (0-30 $\mathrm{min})$; Flow rate: $0.50 \mathrm{~mL} / \mathrm{min}$.

iv) Photoreaction of 9 in DMSO/serum (Figure S5)

To a solution of 9 in DMSO $(2.5 \mathrm{mM}, 400 \mu \mathrm{L})$ in a $4 \mathrm{~mL}$ vial were added fetal bovine serum $(100 \mu \mathrm{L}$, 
Biological Industries, 04-007-1A, Lot. 1837878), a solution of methylene blue in DMSO (10 mM, $10 \mu \mathrm{L}, 10$ mol \%), and a magnetic stir bar under air. The solution was vigorously stirred by a magnetic stirrer at room temperature and photoirradiated for 0-300 sec. After the photoirradiation, a portion of the resulting solution $(15 \mu \mathrm{L})$ was taken by a microsyringe and diluted to a sodium phosphate buffer ( $\mathrm{pH} 7.4,0.10 \mathrm{M}, 2.985 \mathrm{~mL})$ in a 4-side quartz cell. The reaction yields (\%) of 4-methylumbellifenone were determined from the fluorescence intensity of 4-methylumbellifenone at $446 \mathrm{~nm}\left(\lambda_{\mathrm{ex}}=360 \mathrm{~nm}\right)$ produced during the photoreaction. The calibration curve for the fluorescence intensity of 4-methylumbellifenone at $446 \mathrm{~nm}\left(\lambda_{\mathrm{ex}}=360 \mathrm{~nm}, 2.0-10.0\right.$ $\mu \mathrm{M})$ is shown in Figure S5-B.

v) Photoreaction of insulin-indolizine-4-methylumbellifenone conjugate 13 (Scheme 1)

To a solution of 13 in DMSO $(25 \mu \mathrm{M}, 400 \mu \mathrm{L})$ in a $4 \mathrm{~mL}$ vial were added ultrapure water $(100 \mu \mathrm{L})$, a solution of methylene blue in DMSO $(0.10 \mathrm{mM}, 10 \mu \mathrm{L}, 10 \mathrm{~mol} \%)$, and a magnetic stir bar under air. The solution was vigorously stirred by a magnetic stirrer at room temperature and photoirradiated for $60 \mathrm{sec}$. After the photoirradiation, the reaction mixture $(510 \mu \mathrm{L})$ was diluted with a sodium phosphate buffer $(\mathrm{pH} 7.4,0.10$ M, $2.490 \mathrm{~mL}$ ). The resulting solution was transferred to a 4-side quartz cell. The reaction yield (\%) of 4methylumbellifenone was determined from the fluorescence intensity of 4-methylumbellifenone at $446 \mathrm{~nm}$ $\left(\lambda_{\mathrm{ex}}=360 \mathrm{~nm}\right)$.

vi) Oxidation of 1 using 2 (Figure 2B)

To a solution of 1 in acetonitrile ( $2.5 \mathrm{mM}, 400 \mu \mathrm{L}, 1$ equiv) in a $4 \mathrm{~mL}$ vial were added ultrapure water (100 $\mu \mathrm{L})$, a solution of 3-(4-methyl-1,4-epidioxynaphthalen-1(4H)-yl)propanoic acid (2) in acetonitrile (12 mM, $100 \mu \mathrm{L}, 1.2$ equiv), and a magnetic stir bar. The solution was stirred by a magnetic stirrer at $37^{\circ} \mathrm{C}$ under argon atmosphere with shading from light for $1 \mathrm{~h}$. After the reaction, a solution of 1-naphthol in acetonitrile (4.0 mM, $250 \mu \mathrm{L}$ ) was added, and a portion of the resulting solution was subjected to HPLC analysis. The reaction yield (\%) of phenol was determined as $97 \%$ by comparison of the peak area of phenol and that of 1-naphthol as an internal standard. Conditions for HPLC analysis are as below:

Column: L-column3 C18, $5 \mu \mathrm{m}, 4.6 \times 100 \mathrm{~mm}$ (Chemical Evaluation and Research Institution, Japan); Gradient method: $\mathbf{A} / \mathbf{B}=5 / 95$ to $95 / 5$ (0-30 $\mathrm{min})$; Flow rate: $0.50 \mathrm{~mL} / \mathrm{min}$.

vii) Treatment of $\mathbf{1}$ or $\mathbf{6}$ under acidic, basic, and oxidative conditions without photoirradiation (Figure S2-A-C)

To a solution of substrate 1 or 6 in acetonitrile $(2.5 \mathrm{mM}, 400 \mu \mathrm{L}, 1$ equiv) in a $4 \mathrm{~mL}$ vial equipped with a magnetic stir bar was added an aqueous solution of $\mathrm{HCl}(1 \mathrm{M}, 100 \mu \mathrm{L}), \mathrm{NaOH}(1 \mathrm{M}, 100 \mu \mathrm{L})$, or $\mathrm{H}_{2} \mathrm{O}_{2}(1 \mathrm{M}$, $100 \mu \mathrm{L})$. The resulting solution was stirred by a magnetic stirrer at room temperature under argon atmosphere with shading from light for $5 \mathrm{~h}$. After the reaction, a solution of 1-naphthol in acetonitrile $(4.0 \mathrm{mM}, 250 \mu \mathrm{L})$ was added to each solution. A portion of the resulting solution was subjected to HPLC analysis. The reaction yields (\%) were determined by comparison of the peak area of phenol or benzoic acid and that of 1-naphthol as an internal standard. Conditions for HPLC analysis are as below:

Column: L-column3 C18, $5 \mu \mathrm{m}, 4.6 \times 100 \mathrm{~mm}$ (Chemical Evaluation and Research Institution, Japan); Gradient method: For 1, $\mathbf{A} / \mathbf{B}=5 / 95$ to $95 / 5$ (0-30 $\mathrm{min})$; For $\mathbf{6}, \mathbf{A} / \mathbf{C}=5 / 95$ to $95 / 5$ (0-30 min); Flow rate: 0.50 mL/min. 
viii) Stability of compound 9 in serum (Figure S2-D).

To a solution of 9 in DMSO $(2.5 \mathrm{mM}, 400 \mu \mathrm{L})$ in a $4 \mathrm{~mL}$ vial was added fetal bovine serum $(100 \mu \mathrm{L})$. The solution was incubated at $37^{\circ} \mathrm{C}$ under darkness for 10 days. After the indicated time, the solution $(15 \mu \mathrm{L})$ was diluted to $3.0 \mathrm{~mL}$ with a sodium phosphate buffer $(\mathrm{pH} 7.4,0.10 \mathrm{M})$. The resulting solution was transferred to a 4-side quartz cell. The reaction yield (\%) of 4-methylumbellifenone (4-MU) was determined as $17 \%$ from the fluorescence intensity of 4-MU at $446 \mathrm{~nm}\left(\lambda_{\mathrm{ex}}=360 \mathrm{~nm}\right)$.

ix) Stability of insulin-indolizine-4-MU conjugate $\mathbf{1 3}$ in serum in the presence or absence of glutathione (Figure S8).

To a solution of 13 in DMSO $(1.0 \mathrm{mM}, 10 \mu \mathrm{L})$ in a $4 \mathrm{~mL}$ vial were added fetal bovine serum $(490 \mu \mathrm{L})$ and an aqueous solution of glutathione $\left(100 \mathrm{mM}, 0\right.$ or $10 \mu \mathrm{L}, 0$ or 100 equiv). The solution was incubated at $37^{\circ} \mathrm{C}$ under darkness for $0-87 \mathrm{~h}$. After the indicated time, the solution was diluted to $3.0 \mathrm{~mL}$ with a sodium phosphate buffer ( $\mathrm{pH} 7.4,0.10 \mathrm{M})$. The resulting solution was transferred to a 4-side quartz cell. The reaction yield (\%) of 4-methylumbellifenone (4-MU) was determined from the fluorescence intensity of 4-MU at $446 \mathrm{~nm}\left(\lambda_{\mathrm{ex}}=\right.$ $360 \mathrm{~nm})$. 


\section{Synthetic procedures and characterization data}

1-(2-Ethoxy-2-oxoethyl)-2-methylpyridin-1-ium bromide (S1)<smiles>CCOC(=O)C[n+]1ccccc1C</smiles>

Ethyl bromoacetate ( $4.18 \mathrm{~g}, 25.0 \mathrm{mmol}, 1$ equiv), THF (10 mL), and 2-methylpyridine (2.34 g, $25.1 \mathrm{mmol}$, 1.0 equiv) were added into a $20 \mathrm{~mL}$ vial. The resulting solution was stirred at $80{ }^{\circ} \mathrm{C}$ for $12 \mathrm{~h}$ under argon atmosphere. After cooling to room temperature, the reaction mixture was poured into hexane $(50 \mathrm{~mL})$ to form a precipitate. The precipitate was collected by filtration, washed with hexane $(10 \mathrm{~mL} \times 3)$, and dried up under high vacuum to afford the product;

Yield $5.99 \mathrm{~g}(23.0 \mathrm{mmol}, 92.0 \%)$;

Colorless solid (mp $\left.122-123{ }^{\circ} \mathrm{C}\right)$;

${ }^{1} \mathrm{H} \mathrm{NMR}\left(\mathrm{CDCl}_{3}, 400 \mathrm{MHz}\right): \delta 9.81(\mathrm{~d}, J=6.4 \mathrm{~Hz}, 1 \mathrm{H}), 8.38(\mathrm{ddd}, J=8.4,7.6,1.2 \mathrm{~Hz}, 1 \mathrm{H}), 7.94(\mathrm{dd}, J=7.6$, $6.4 \mathrm{~Hz}, 1 \mathrm{H}), 7.85(\mathrm{~d}, J=8.4 \mathrm{~Hz}, 1 \mathrm{H}), 6.22(\mathrm{~s}, 2 \mathrm{H}), 4.32$ (q, $J=7.2 \mathrm{~Hz}, 2 \mathrm{H}), 2.92(\mathrm{~s}, 3 \mathrm{H}), 1.35(\mathrm{t}, J=7.2 \mathrm{~Hz}$, $3 \mathrm{H})$;

${ }^{13} \mathrm{C}\{1 \mathrm{H}\} \mathrm{NMR}\left(\mathrm{CDCl}_{3}, 100 \mathrm{MHz}\right): \delta 165.6(1 \mathrm{C}), 156.4(1 \mathrm{C}), 148.0(1 \mathrm{C}), 146.2(1 \mathrm{C}), 129.9(1 \mathrm{C}), 125.9(1 \mathrm{C})$, 63.5 (1C), $59.2(1 \mathrm{C}), 21.3(1 \mathrm{C}), 14.2(1 \mathrm{C})$;

IR $\left(\mathrm{ZnSe}, \mathrm{cm}^{-1}\right)$ 729, 775, 1016, 1196, 1215, 1632, 1744, 2990, 3416;

HRMS (ESI) $m / z$ : [M - Br] $]^{+}$Calcd for $\mathrm{C}_{10} \mathrm{H}_{14} \mathrm{NO}_{2}{ }^{+}$180.1019; Found 180.1019.

2-Methoxyindolizine (S2)

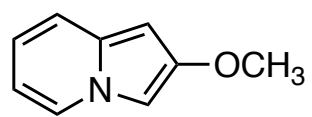

1-(2-Ethoxy-2-oxoethyl)-2-methylpyridin-1-ium bromide (S1, $2.35 \mathrm{~g}, 9.00 \mathrm{mmol}, 1$ equiv), DMF (45 mL), and $i$-PrOH $(45 \mathrm{~mL})$ were added into a $300 \mathrm{~mL}$ round-bottom flask. The flask was filled with argon and set into an ice water bath. Cesium hydroxide monohydrate ( $3.04 \mathrm{~g}, 18.1 \mathrm{mmol}, 2.0$ equiv) was added to the solution in one portion. The resulting mixture was stirred at room temperature for $30 \mathrm{~min}$. Then, dimethyl sulfate (1.14 g, $9.04 \mathrm{mmol}, 1.0$ equiv) was added dropwise to the mixture over $5 \mathrm{~min}$ at room temperature, and the mixture was further stirred at room temperature for $2 \mathrm{~h}$. The mixture was then poured into a solution of hexane (300 $\mathrm{mL})$ and EtOAc $(150 \mathrm{~mL})$, and washed with brine $(300 \mathrm{~mL} \times 3)$. The organic layer was dried with sodium sulfate and evaporated. The residue was purified by silica-gel column chromatography (hexane/EtOAc $=1 / 0$ to $23 / 2$ ) to afford the product;

Yield $353 \mathrm{mg}$ (2.40 mmol, 26.7\%);

Colorless solid (mp 79-81 ${ }^{\circ} \mathrm{C}$ );

TLC $R \mathrm{f}=0.33(n$-hexane:EtOAc $=10: 1)$;

${ }^{1} \mathrm{H} \mathrm{NMR}\left(\mathrm{CDCl}_{3}, 400 \mathrm{MHz}\right): \delta 7.79(\mathrm{dd}, J=7.2,1.2 \mathrm{~Hz}, 1 \mathrm{H}), 7.20(\mathrm{~d}, J=9.2 \mathrm{~Hz}, 1 \mathrm{H}), 6.96(\mathrm{~d}, J=2.0 \mathrm{~Hz}$, $1 \mathrm{H}), 6.66-6.62(\mathrm{~m}, 1 \mathrm{H}), 6.42-6.38(\mathrm{~m}, 1 \mathrm{H}), 6.06(\mathrm{~s}, 1 \mathrm{H}), 3.83(\mathrm{~s}, 3 \mathrm{H})$;

${ }^{13} \mathrm{C}\{1 \mathrm{H}\} \mathrm{NMR}\left(\mathrm{CDCl}_{3}, 100 \mathrm{MHz}\right): \delta 153.1(1 \mathrm{C}), 131.2(1 \mathrm{C}), 125.0(1 \mathrm{C}), 117.7(1 \mathrm{C}), 117.4(1 \mathrm{C}), 109.3(1 \mathrm{C})$, $96.4(1 \mathrm{C}), 86.1(1 \mathrm{C}), 57.8(1 \mathrm{C})$; 
IR $\left(\mathrm{ZnSe}, \mathrm{cm}^{-1}\right)$ 754, 1032, 1350, 1553, 1632, 1746, 2313, 2961;

HRMS (ESI) $m / z$ : $[\mathrm{M}+\mathrm{H}]^{+}$Calcd for $\mathrm{C}_{9} \mathrm{H}_{10} \mathrm{NO}^{+}$148.0757; Found 148.0756.

Phenyl 2-methoxyindolizine-3-carboxylate (1)<smiles>COc1cc2ccccn2c1C(=O)Oc1ccccc1</smiles>

2-Methoxyindolizine (S2, $44.2 \mathrm{mg}, 0.300 \mathrm{mmol}, 1$ equiv) and THF (0.50 mL) were added into a $4 \mathrm{~mL}$ vial. The vial was filled with argon and set into an ice-water bath. A solution of phenyl chloroformate $(56.6 \mathrm{mg}$, $0.362 \mathrm{mmol}, 1.2$ equiv) in THF $(1.0 \mathrm{~mL})$ was added into the vial dropwise. The resulting mixture was stirred at room temperature for $4 \mathrm{~h}$. The mixture was then poured into a mixture of EtOAc $(15 \mathrm{~mL})$ and saturated aqueous $\mathrm{NaHCO}_{3}$ solution $(10 \mathrm{~mL})$, and extracted with EtOAc $(15 \mathrm{~mL} \times 3)$. The combined organic layer was dried with $\mathrm{Na}_{2} \mathrm{SO}_{4}$ and evaporated. The residue was purified by silica-gel column chromatography (hexane/EtOAc $=1 / 0$ to $1 / 1$ ) to afford the product;

Yield $66.2 \mathrm{mg}$ (0.248 mmol, 82.4\%);

Colorless solid (mp 96-98 ${ }^{\circ} \mathrm{C}$ );

$\mathrm{TLC} R \mathrm{f}=0.46(n$-hexane:EtOAc $=4: 1)$;

${ }^{1} \mathrm{H}$ NMR $\left(\mathrm{CDCl}_{3}, 400 \mathrm{MHz}\right): \delta 9.43(\mathrm{~d}, J=7.2 \mathrm{~Hz}, 1 \mathrm{H}), 7.44-7.36(\mathrm{~m}, 3 \mathrm{H}), 7.24-7.22(\mathrm{~m}, 3 \mathrm{H}), 7.12-7.08(\mathrm{~m}$, $1 \mathrm{H}), 6.80-6.76(\mathrm{~m}, 1 \mathrm{H}), 6.11(\mathrm{~s}, 1 \mathrm{H}), 4.01(\mathrm{~s}, 3 \mathrm{H})$;

${ }^{13} \mathrm{C}\{1 \mathrm{H}\} \mathrm{NMR}\left(\mathrm{CDCl}_{3}, 100 \mathrm{MHz}\right): \delta 160.1(1 \mathrm{C}), 158.5(1 \mathrm{C}), 150.9(1 \mathrm{C}), 137.3(1 \mathrm{C}), 129.4(2 \mathrm{C}), 128.0(1 \mathrm{C})$, 125.5 (1C), 123.9(1C), 122.5 (2C), 117.2 (1C), 112.2 (1C), 100.9 (1C), 85.5 (1C), 58.2 (1C);

IR $\left(\mathrm{ZnSe}, \mathrm{cm}^{-1}\right)$ 737, 1092, 1192, 1225, 1312, 1344, 1418, 1678;

HRMS (ESI) $m / z$ : [M + H] $]^{+}$Calcd for $\mathrm{C}_{16} \mathrm{H}_{14} \mathrm{NO}_{3}{ }^{+}$268.0968; Found 268.0968.

Ethyl (E)-3-(4-phenylpiperazin-1-yl)acrylate (3)<smiles>CCOC(=O)/C=C/N1CCN(c2ccccc2)CC1</smiles>

Ethyl propiolate (196 mg, $2.00 \mathrm{mmol}, 1$ equiv) and THF ( $8 \mathrm{~mL}$ ) was added into a $20 \mathrm{~mL}$ vial. The vial was filled with argon and set into an ice-water bath. 1-Phenylpiperazine ( $334 \mathrm{mg}, 2.06 \mathrm{mmol}, 1.0$ equiv) was added into the vial dropwise. The resulting mixture was stirred at room temperature for $1 \mathrm{~h}$. The solution was concentrated, and the residue was purified by silica-gel column chromatography (hexane/EtOAc $=1 / 0$ to $0 / 1$ ) to afford the product;

Yield $323 \mathrm{mg}$ (1.24 mmol, 62.1\%)

Colorless solid (mp $\left.63-65^{\circ} \mathrm{C}\right)$;

TLC $R \mathrm{f}=0.58(n$-hexane:EtOAc $=1: 1)$;

${ }^{1} \mathrm{H}$ NMR $\left(\mathrm{CDCl}_{3}, 400 \mathrm{MHz}\right): \delta 7.43(\mathrm{~d}, J=13.2 \mathrm{~Hz}, 1 \mathrm{H}), 7.31-7.27(\mathrm{~m}, 2 \mathrm{H}), 6.94-6.90(\mathrm{~m}, 3 \mathrm{H}), 4.73(\mathrm{~d}, J=$ $13.2 \mathrm{~Hz}, 1 \mathrm{H}), 4.15$ (q, $J=6.8 \mathrm{~Hz}, 2 \mathrm{H}), 3.39-3.37$ (m, 4H), 3.21-3.19 (m, 4H), 1.27 (t, $J=6.8 \mathrm{~Hz}, 3 \mathrm{H})$;

${ }^{13} \mathrm{C}\{1 \mathrm{H}\} \mathrm{NMR}\left(\mathrm{CDCl}_{3}, 100 \mathrm{MHz}\right): \delta 169.7$ (1C), $151.6(1 \mathrm{C}), 151.0(1 \mathrm{C}), 129.4(2 \mathrm{C}), 120.8(1 \mathrm{C}), 116.9(2 \mathrm{C})$, 
85.9 (1C), $59.2(1 \mathrm{C}), 49.2(4 \mathrm{C}), 14.7(1 \mathrm{C})$;

IR $\left(\mathrm{ZnSe}, \mathrm{cm}^{-1}\right) 768,793,1015,1148,1229,1377,1597,1682,2828$;

HRMS (ESI) $m / z$ : [M + H] $]^{+}$Calcd for $\mathrm{C}_{15} \mathrm{H}_{21} \mathrm{~N}_{2} \mathrm{O}_{2}{ }^{+}$261.1598; Found 261.1597.

Benzyl 2-methoxyindolizine-3-carboxylate (4)<smiles>COc1cc2ccccn2c1C(=O)OCc1ccccc1</smiles>

2-Methoxyindolizine (S2, $58.9 \mathrm{mg}, 0.400 \mathrm{mmol}, 1$ equiv) and THF $(0.50 \mathrm{~mL})$ were added into a $4 \mathrm{~mL}$ vial. The vial was filled with argon and set into an ice-water bath. A solution of benzyl chloroformate $(82.6 \mathrm{mg}$, $0.484 \mathrm{mmol}, 1.2$ equiv) in THF $(1.0 \mathrm{~mL})$ was added into the vial dropwise. The resulting mixture was stirred at room temperature for $20 \mathrm{~h}$. The mixture was then poured into a mixture of EtOAc $(15 \mathrm{~mL})$ and saturated aqueous $\mathrm{NaHCO}_{3}$ solution $(10 \mathrm{~mL})$, extracted with EtOAc $(15 \mathrm{~mL} \times 3)$. The combined organic layer was dried with $\mathrm{Na}_{2} \mathrm{SO}_{4}$ and evaporated. The residue was purified by silica-gel column chromatography (hexane/EtOAc $=1 / 0$ to $1 / 1)$ to afford the product;

Yield $89.3 \mathrm{mg}$ (0.317 mmol, 79.3\%);

Pale yellow solid (mp $\left.54-56{ }^{\circ} \mathrm{C}\right)$;

TLC $R \mathrm{f}=0.53(n$-hexane:EtOAc $=2: 1)$;

${ }^{1} \mathrm{H}$ NMR $\left(\mathrm{CDCl}_{3}, 400 \mathrm{MHz}\right): \delta 9.41(\mathrm{~d}, J=8.0 \mathrm{~Hz}, 1 \mathrm{H}), 7.52-7.50(\mathrm{~m}, 2 \mathrm{H}), 7.39-7.30(\mathrm{~m}, 4 \mathrm{H}), 7.06-7.02(\mathrm{~m}$, 1H), 6.74 (ddd, $J=7.1,7.1,1.6 \mathrm{~Hz}, 1 \mathrm{H}), 6.06(\mathrm{~s}, 1 \mathrm{H}), 5.43$ (s, 2H), 3.98 (s, 3H);

${ }^{13} \mathrm{C}\{1 \mathrm{H}\} \mathrm{NMR}\left(\mathrm{CDCl}_{3}, 100 \mathrm{MHz}\right): \delta 161.4(1 \mathrm{C}), 158.2(1 \mathrm{C}), 137.2(1 \mathrm{C}), 136.4(1 \mathrm{C}), 128.5(2 \mathrm{C}), 127.8(1 \mathrm{C})$, 127.7 (1C), 127.5 (2C), 123.1 (1C), 117.1 (1C), 111.9 (1C), 101.4 (1C), 85.3 (1C), 65.0 (1C), 58.1 (1C);

IR $\left(\mathrm{ZnSe}, \mathrm{cm}^{-1}\right)$ 764, 1026, 1099, 1225, 1308, 1422, 1659, 2936;

HRMS (ESI) $m / z$ : $[\mathrm{M}+\mathrm{H}]^{+}$Calcd for $\mathrm{C}_{17} \mathrm{H}_{16} \mathrm{NO}_{3}{ }^{+} 282.1125$; Found 282.1125.

4-Nitrophenyl 2-methoxyindolizine-3-carboxylate (5)<smiles>COc1cc2ccccn2c1C(=O)Oc1ccc([N+](=O)[O-])cc1</smiles>

2-Methoxyindolizine (S2, $44.2 \mathrm{mg}, 0.300 \mathrm{mmol}, 1$ equiv) and THF $(0.50 \mathrm{~mL})$ were added into a $4 \mathrm{~mL}$ vial. The vial was filled with argon and set into an ice-water bath. A solution of 4-nitrophenyl chloroformate (72.6 $\mathrm{mg}, 0.334 \mathrm{mmol}, 1.1$ equiv) in THF $(1.0 \mathrm{~mL})$ was added into the vial dropwise. The resulting mixture was stirred at room temperature for $4 \mathrm{~h}$. The mixture was then poured into a mixture of EtOAc $(15 \mathrm{~mL})$ and saturated aqueous $\mathrm{NaHCO}_{3}$ solution $(10 \mathrm{~mL})$, and extracted with EtOAc $(15 \mathrm{~mL} \times 3)$. The combined organic layer was dried with $\mathrm{Na}_{2} \mathrm{SO}_{4}$ and evaporated. The residue was purified by silica-gel column chromatography 
(hexane/EtOAc $=1 / 0$ to $1 / 1)$ to afford the product;

Yield $83.2 \mathrm{mg}(0.266 \mathrm{mmol}, 88.9 \%)$;

Colorless solid (mp $\left.137-139^{\circ} \mathrm{C}\right)$;

TLC $R \mathrm{f}=0.30(n$-hexane:EtOAc $=4: 1)$;

${ }^{1} \mathrm{H}$ NMR $\left(\mathrm{CDCl}_{3}, 400 \mathrm{MHz}\right): \delta 9.39(\mathrm{~d}, J=7.2 \mathrm{~Hz}, 1 \mathrm{H}), 8.32-8.30\left(\mathrm{AA}^{\prime} \mathrm{BB}^{\prime}, 2 \mathrm{H}\right), 7.46-7.39(\mathrm{~m}, 3 \mathrm{H}), 7.19-$ $7.14(\mathrm{~m}, 1 \mathrm{H}), 6.86-6.82(\mathrm{~m}, 1 \mathrm{H}), 6.12(\mathrm{~s}, 1 \mathrm{H}), 4.02(\mathrm{~s}, 3 \mathrm{H})$;

${ }^{13} \mathrm{C}\{1 \mathrm{H}\} \mathrm{NMR}\left(\mathrm{CDCl}_{3}, 100 \mathrm{MHz}\right): \delta 156.2(1 \mathrm{C}), 152.3(1 \mathrm{C}), 138.1(1 \mathrm{C}), 129.4(1 \mathrm{C}), 128.0(1 \mathrm{C}), 125.24(1 \mathrm{C})$, 125.16 (1C), 124.7 (1C), 123.0 (1C), 122.4 (1C), 121.0 (1C), 117.3 (1C), 117.0 (1C), 112.7 (1C), 85.8 (1C), $58.3(1 \mathrm{C})$;

IR $\left(\mathrm{ZnSe}, \mathrm{cm}^{-1}\right)$ 694, 1005, 1094, 1225, 1514, 1682, 1726;

HRMS (ESI) $m / z$ : $[\mathrm{M}+\mathrm{H}]^{+}$Calcd for $\mathrm{C}_{16} \mathrm{H}_{13} \mathrm{~N}_{2} \mathrm{O}_{5}{ }^{+}$313.0819; Found 313.0817.

2-Methoxyindolizin-3-yl phenyl ketone (6)<smiles>COc1cc2ccccn2c1C(=O)c1ccccc1</smiles>

2-Methoxyindolizine (S2, $44.2 \mathrm{mg}, 0.300 \mathrm{mmol}, 1$ equiv) and THF $(0.50 \mathrm{~mL})$ were added into a $4 \mathrm{~mL}$ vial. The vial was filled with argon and set into an ice-water bath. A solution of benzoyl chloride (50.4 mg, 0.359 mmol, 1.2 equiv) in THF $(1.0 \mathrm{~mL})$ was added into the vial dropwise. The resulting mixture was stirred at room temperature for $1 \mathrm{~h}$. The mixture was then poured into a mixture of EtOAc $(15 \mathrm{~mL})$ and saturated aqueous $\mathrm{NaHCO}_{3}$ solution $(10 \mathrm{~mL})$, and extracted with EtOAc $(15 \mathrm{~mL} \times 3)$. The combined organic layer was dried with $\mathrm{Na}_{2} \mathrm{SO}_{4}$ and evaporated. The residue was purified by silica-gel column chromatography (hexane/EtOAc $=1 / 0$ to $1 / 1)$ to afford the product;

Yield $63.6 \mathrm{mg}(0.253 \mathrm{mmol}, 84.3 \%)$;

Pale yellow solid (mp $60-61^{\circ} \mathrm{C}$ );

TLC $R \mathrm{f}=0.44(n$-hexane:EtOAc $=4: 1)$;

${ }^{1} \mathrm{H} \mathrm{NMR}\left(\mathrm{CDCl}_{3}, 400 \mathrm{MHz}\right): \delta 9.85(\mathrm{~d}, J=8.0 \mathrm{~Hz}, 1 \mathrm{H}), 7.69-7.66(\mathrm{~m}, 2 \mathrm{H}), 7.49-7.36(\mathrm{~m}, 4 \mathrm{H}), 7.19-7.15(\mathrm{~m}$, $1 \mathrm{H}), 6.86-6.82(\mathrm{~m}, 1 \mathrm{H}), 6.01(\mathrm{~s}, 1 \mathrm{H}), 3.70(\mathrm{~s}, 3 \mathrm{H})$;

${ }^{13} \mathrm{C}\{1 \mathrm{H}\}$ NMR $\left(\mathrm{CDCl}_{3}, 100 \mathrm{MHz}\right): \delta 183.9(1 \mathrm{C}), 158.4$ (1C), $141.3(1 \mathrm{C}), 138.0(1 \mathrm{C}), 130.4(1 \mathrm{C}), 128.7$ (2C + 1C), 127.6 (2C), 125.3 (1C), 117.0 (1C), 112.7 (1C), 111.5 (1C), 85.4 (1C), 57.6 (1C);

IR $\left(\mathrm{ZnSe}, \mathrm{cm}^{-1}\right)$ 696, 743, 1053, 1342, 1418, 1503, 1557;

HRMS (ESI) $m / z$ : [M $+\mathrm{H}]^{+}$Calcd for $\mathrm{C}_{16} \mathrm{H}_{14} \mathrm{NO}_{2}{ }^{+}$252.1019; Found 252.1019. 
<smiles>COc1cc2ccccn2c1C(=O)CCc1ccccc1</smiles>

3-Phenylpropionic acid (33.0 mg, $0.220 \mathrm{mmol}, 1.1$ equiv) and thionyl chloride ( $0.50 \mathrm{~mL})$ was added into a $20 \mathrm{~mL}$ vial. The resulting solution was stirred at $80^{\circ} \mathrm{C}$ for $2 \mathrm{~h}$ under argon atmosphere. After cooling to room temperature, thionyl chloride was evaporated and the residue was dried up under vacuum. THF (1.0 mL) was added into the vial. The vial was filled with argon and set into an ice-water bath. Then, a solution of 2methoxylindolizine (S2, $29.4 \mathrm{mg}, 0.200 \mathrm{mmol}, 1$ equiv) in THF $(1.0 \mathrm{~mL})$ was added into the vial dropwise. The resulting mixture was stirred at room temperature for $1 \mathrm{~h}$. The mixture was then poured into a mixture of EtOAc $(15 \mathrm{~mL})$ and saturated aqueous $\mathrm{NaHCO}_{3}$ solution $(10 \mathrm{~mL})$, and extracted with EtOAc $(15 \mathrm{~mL} \times 3)$. The combined organic layer was dried with $\mathrm{Na}_{2} \mathrm{SO}_{4}$ and evaporated. The residue was purified by silica-gel column chromatography (hexane/EtOAc $=1 / 0$ to $1 / 1$ ) to afford the product;

Yield $33.2 \mathrm{mg}$ (0.119 mmol, 59.5\%);

Pale yellow solid (mp 94-96 ${ }^{\circ} \mathrm{C}$ );

TLC $R \mathrm{f}=0.44(n$-hexane:EtOAc $=4: 1)$;

${ }^{1} \mathrm{H}$ NMR $\left(\mathrm{CDCl}_{3}, 400 \mathrm{MHz}\right): \delta 9.98(\mathrm{~d}, J=6.4 \mathrm{~Hz}, 1 \mathrm{H}), 7.36-7.30(\mathrm{~m}, 5 \mathrm{H}), 7.22-7.17(\mathrm{~m}, 1 \mathrm{H}), 7.15-7.11(\mathrm{~m}$, $1 \mathrm{H}), 6.81-6.78(\mathrm{~m}, 1 \mathrm{H}), 6.02(\mathrm{~s}, 1 \mathrm{H}), 3.98(\mathrm{~s}, 3 \mathrm{H}), 3.25-3.21(\mathrm{~m}, 2 \mathrm{H}), 3.07-3.03(\mathrm{~m}, 2 \mathrm{H})$;

${ }^{13} \mathrm{C}\{1 \mathrm{H}\} \mathrm{NMR}\left(\mathrm{CDCl}_{3}, 100 \mathrm{MHz}\right): \delta 187.9(1 \mathrm{C}), 158.8(1 \mathrm{C}), 142.4(1 \mathrm{C}), 137.0(1 \mathrm{C}), 128.8(1 \mathrm{C}), 128.6(2 \mathrm{C})$, 128.4 (2C), 125.8 (1C), 124.9 (1C), 116.8 (1C), 112.6 (1C), 111.4 (1C), 85.1 (1C), 57.9 (1C), 42.7 (1C), 31.5 (1C);

IR $\left(\mathrm{ZnSe}, \mathrm{cm}^{-1}\right) 768,1082,1414,1460,1503,1597,2926$;

HRMS (ESI) $m / z$ : $[\mathrm{M}+\mathrm{H}]^{+}$Calcd for $\mathrm{C}_{18} \mathrm{H}_{18} \mathrm{NO}_{2}{ }^{+} 280.1332$; Found 280.1332 .

2-Methoxyindolizin-3-yl 4-(1-(3,5,5,8,8-pentamethyl-5,6,7,8-tetrahydronaphthalen-2-yl)vinyl)phenyl ketone (8)<smiles>C=C(c1ccc(C(=O)c2c(OC)cc3ccccn23)cc1)c1cc2c(cc1C)C(C)(C)CCC2(C)C</smiles>

Bexarotene (52.3 mg, $0.150 \mathrm{mmol}, 1$ equiv), $\mathrm{CH}_{2} \mathrm{Cl}_{2}(1.5 \mathrm{~mL})$, and DMF (1.0 $\left.\mu \mathrm{L}, 13 \mu \mathrm{mol}, 8.6 \mathrm{~mol} \%\right)$ were added into a $20 \mathrm{~mL}$ vial. The vial was filled with argon and set into an ice-water bath. Oxalyl chloride (38.6 $\mu \mathrm{L} 0.447 \mathrm{mmol}, 3.0$ equiv) was added into the vial dropwise. The resulting solution was stirred at room temperature for $16 \mathrm{~h}$. The solution was concentrated, and the residue was dried up under vacuum. THF (1.5 
$\mathrm{mL}$ ) was added into the vial. The vial was filled with argon and set into an ice-water bath. A solution of 2methoxylindolizine (S2, $29.4 \mathrm{mg}, 0.200 \mathrm{mmol}, 1.3$ equiv) in THF (1.0 mL) was added into the vial dropwise. The resulting mixture was stirred at room temperature for $4 \mathrm{~h}$. The mixture was then poured into a mixture of EtOAc $(15 \mathrm{~mL})$ and saturated aqueous $\mathrm{NaHCO}_{3}$ solution $(10 \mathrm{~mL})$, and extracted with EtOAc $(15 \mathrm{~mL} \times 3)$. The combined organic layer was dried with $\mathrm{Na}_{2} \mathrm{SO}_{4}$ and evaporated. The residue was purified by silica-gel column chromatography (hexane/EtOAc $=1 / 0$ to $1 / 1$ ) to afford the product;

Yield $67.8 \mathrm{mg}(0.142 \mathrm{mmol}, 94.6 \%)$;

Pale yellow solid $\left(130^{\circ} \mathrm{C}\right.$, decomposed);

TLC $R \mathrm{f}=0.57(n$-hexane:EtOAc $=2: 1)$;

${ }^{1} \mathrm{H} \mathrm{NMR}\left(\mathrm{CDCl}_{3}, 400 \mathrm{MHz}\right): \delta 9.83(\mathrm{~d}, J=7.6 \mathrm{~Hz}, 1 \mathrm{H}), 7.62-7.59(\mathrm{~m}, 2 \mathrm{H}), 7.38-7.31(\mathrm{~m}, 3 \mathrm{H}), 7.18-7.14(\mathrm{~m}$, 2H), $7.08(\mathrm{~s}, 1 \mathrm{H}), 6.85-6.81(\mathrm{~m}, 1 \mathrm{H}), 6.00(\mathrm{~s}, 1 \mathrm{H}), 5.81(\mathrm{~d}, J=1.6 \mathrm{~Hz}, 1 \mathrm{H}), 5.28(\mathrm{~d}, J=1.6 \mathrm{~Hz}, 1 \mathrm{H}), 3.70(\mathrm{~s}$, $3 \mathrm{H}), 1.99(\mathrm{~s}, 3 \mathrm{H}), 1.70(\mathrm{~s}, 4 \mathrm{H}), 1.31(\mathrm{~s}, 6 \mathrm{H}), 1.29(\mathrm{~s}, 6 \mathrm{H})$;

${ }^{13} \mathrm{C}\{1 \mathrm{H}\} \mathrm{NMR}\left(\mathrm{CDCl}_{3}, 100 \mathrm{MHz}\right): \delta 183.6(1 \mathrm{C}), 158.3$ (1C), $149.8(1 \mathrm{C}), 144.2(1 \mathrm{C}), 143.1(1 \mathrm{C}), 142.2(1 \mathrm{C})$, 140.2 (1C), 138.6 (1C), 137.9 (1C), 133.0 (1C), 128.9 (2C), 128.7 (1C), 128.2 (1C), 128.0 (1C), 125.9 (2C), 125.2 (1C), 117.0 (1C), 115.7 (1C), 112.7 (1C), 111.7 (1C), 85.4 (1C), 57.6 (1C), $35.3(1 \mathrm{C}+1 \mathrm{C}), 34.1(1 \mathrm{C})$, 34.0 (1C), 32.04 (2C), 31.99 (2C), 20.1 (1C);

IR $\left(\mathrm{ZnSe}, \mathrm{cm}^{-1}\right)$ 766, 1061, 1346, 1445, 1462, 1504, 1576, 2959;

HRMS (ESI) $m / z$ : $[\mathrm{M}+\mathrm{H}]^{+}$Calcd for $\mathrm{C}_{33} \mathrm{H}_{36} \mathrm{NO}_{2}{ }^{+}$478.2741; Found 478.2740.

4-Methyl-2-oxo-2H-chromen-7-yl 2-methoxyindolizine-3-carboxylate (9)<smiles>COc1cc2ccccn2c1C(=O)Oc1ccc2c(C)cc(=O)oc2c1</smiles>

4-Methylumbelliferone ( $84.6 \mathrm{mg}, 0.482 \mathrm{mmol}, 1.2$ equiv) and DMF $(0.60 \mathrm{~mL})$ were added into a $4 \mathrm{~mL}$ vial. The vial was filled with argon and set into an ice-water bath. Potassium tert-butoxide $(49.4 \mathrm{mg}, 0.440 \mathrm{mmol}$, 1.1 equiv) was added into the vial in one portion, and the resulting mixture was stirred at room temperature for $1 \mathrm{~h}$. Then, a solution of 4-nitrophenyl 2-methoxyindolizine-3-carboxylate (5, $125 \mathrm{mg}, 0.400 \mathrm{mmol}, 1$ equiv) in THF $(0.60 \mathrm{~mL})$ was added into the vial dropwise. The resulting mixture was stirred at room temperature for $20 \mathrm{~h}$. The mixture was then poured into a mixture of EtOAc $(15 \mathrm{~mL})$ and saturated aqueous $\mathrm{NaHCO}_{3}$ solution $(10 \mathrm{~mL})$, and extracted with EtOAc $(15 \mathrm{~mL} \times 3)$. The combined organic layer was dried with $\mathrm{Na}_{2} \mathrm{SO}_{4}$ and evaporated. The residue was purified by silica-gel column chromatography (hexane/EtOAc $=1 / 0$ to $0 / 1$ ). The product was further purified by GPC (YMC-GPC T2000, $21.2 \times 600 \mathrm{~mm}$, chloroform) to afford the product; Yield $28.0 \mathrm{mg}(80.2 \mu \mathrm{mol}, 20.0 \%)$;

Colorless solid (mp 218-219 ${ }^{\circ} \mathrm{C}$ );

$\mathrm{TLC} R \mathrm{f}=0.43(n$-hexane:EtOAc $=1: 1)$; 
${ }^{1} \mathrm{H}$ NMR $\left(\mathrm{CDCl}_{3}, 400 \mathrm{MHz}\right): \delta 9.40(\mathrm{~d}, J=8.0 \mathrm{~Hz}, 1 \mathrm{H}), 7.64(\mathrm{~d}, J=8.4 \mathrm{~Hz}, 1 \mathrm{H}), 7.41-7.38(\mathrm{~m}, 1 \mathrm{H}), 7.29-$ $7.24(\mathrm{~m}, 2 \mathrm{H}), 7.17-7.13(\mathrm{~m}, 1 \mathrm{H}), 6.85-6.81(\mathrm{~m}, 1 \mathrm{H}), 6.27(\mathrm{~d}, J=1.6 \mathrm{~Hz}, 1 \mathrm{H}), 6.12(\mathrm{~s}, 1 \mathrm{H}), 4.03(\mathrm{~s}, 3 \mathrm{H}), 2.46$ $(\mathrm{d}, J=1.6 \mathrm{~Hz}, 3 \mathrm{H})$;

${ }^{13} \mathrm{C}\{1 \mathrm{H}\} \mathrm{NMR}\left(\mathrm{CDCl}_{3}, 100 \mathrm{MHz}\right): \delta 160.9(1 \mathrm{C}), 159.1$ (1C), $158.8(1 \mathrm{C}), 154.3(1 \mathrm{C}), 153.8(1 \mathrm{C}), 152.2(1 \mathrm{C})$, 137.9 (1C), 128.0 (1C), 125.2 (1C), 124.5 (1C), 119.1 (1C), 117.5 (1C), 117.3 (1C), 114.2 (1C), 112.5 (1C), 111.2 (1C), $100.4(1 \mathrm{C}), 85.7$ (1C), 58.3 (1C), 18.9 (1C);

IR $\left(\mathrm{ZnSe}, \mathrm{cm}^{-1}\right)$ 754, 1003, 1136, 1422, 1614, 1661, 1678, 1726;

HRMS (ESI) $m / z:[\mathrm{M}+\mathrm{H}]^{+}$Calcd for $\mathrm{C}_{20} \mathrm{H}_{16} \mathrm{NO}_{5}{ }^{+} 350.1023$; Found 350.1022 .

Phenyl 2-methylindolizine-3-carboxylate (10)<smiles>Cc1cc2ccccn2c1C(=O)O</smiles>

2-Methylindolizine (131 mg, $1.00 \mathrm{mmol}, 1$ equiv) and THF (2.5 mL) was added into a $20 \mathrm{~mL}$ vial. The vial was filled with argon and set into an ice-water bath. A solution of phenyl chloroformate $(235 \mathrm{mg}, 1.50 \mathrm{mmol}$, 1.5 equiv) in THF $(1.0 \mathrm{~mL})$ was added into the vial dropwise. The resulting mixture was stirred at room temperature for $16 \mathrm{~h}$. The mixture was then poured into a mixture of EtOAc $(15 \mathrm{~mL})$ and saturated aqueous $\mathrm{NaHCO}_{3}$ solution $(10 \mathrm{~mL})$, then extracted with EtOAc $(15 \mathrm{~mL} \times 3)$. The combined organic layer was dried with $\mathrm{Na}_{2} \mathrm{SO}_{4}$ and evaporated. The residue was purified by silica-gel column chromatography (hexane/EtOAc $=1 / 0$ to $4 / 1)$ to afford the product;

Yield $126 \mathrm{mg}$ (0.501 mmol, 50.2\%);

Pale yellow solid $\left(\operatorname{mp~} 55-56{ }^{\circ} \mathrm{C}\right)$;

TLC $R \mathrm{f}=0.63(n$-hexane:EtOAc $=4: 1)$;

${ }^{1} \mathrm{H}$ NMR $\left(\mathrm{CDCl}_{3}, 400 \mathrm{MHz}\right): \delta 9.47(\mathrm{~d}, J=7.6 \mathrm{~Hz}, 1 \mathrm{H}), 7.46-7.41(\mathrm{~m}, 3 \mathrm{H}), 7.28-7.23(\mathrm{~m}, 3 \mathrm{H}), 7.07-7.03(\mathrm{~m}$, $1 \mathrm{H}), 6.79-6.75(\mathrm{~m}, 1 \mathrm{H}), 6.40(\mathrm{~s}, 1 \mathrm{H}), 2.67(\mathrm{~s}, 3 \mathrm{H})$;

${ }^{13} \mathrm{C}\{1 \mathrm{H}\} \mathrm{NMR}\left(\mathrm{CDCl}_{3}, 100 \mathrm{MHz}\right): \delta 160.6(1 \mathrm{C}), 150.7(1 \mathrm{C}), 138.1(1 \mathrm{C}), 135.8(1 \mathrm{C}), 129.5(2 \mathrm{C}), 128.1(1 \mathrm{C})$, 125.6 (1C), 122.9 (1C), 122.3 (2C), 117.8 (1C), 112.5 (1C), 111.2 (1C), 104.3 (1C), $15.6(1 \mathrm{C})$;

IR $\left(\mathrm{ZnSe}, \mathrm{cm}^{-1}\right)$ 750, 986, 1061, 1161, 1182, 1198, 1410, 1680, 1773;

HRMS (ESI) $m / z$ : $[\mathrm{M}+\mathrm{H}]^{+}$Calcd for $\mathrm{C}_{16} \mathrm{H}_{14} \mathrm{NO}_{2}{ }^{+}$252.1019; Found 252.1017.

1-(2-Oxo-2-phenoxyethyl)pyridin-1-ium bromide (S4)<smiles>O=C(C[n+]1ccccc1)c1ccccc1</smiles>

Phenyl bromoacetate (1.08 g, $5.02 \mathrm{mmol}, 1.0$ equiv), THF (5 mL), and pyridine (396 mg, $5.01 \mathrm{mmol}, 1$ equiv) were added into a $20 \mathrm{~mL}$ vial. The resulting solution was stirred at $60{ }^{\circ} \mathrm{C}$ for $12 \mathrm{~h}$ under argon atmosphere. After cooling to room temperature, the reaction mixture was poured into hexane $(50 \mathrm{~mL})$ to form a precipitate. The precipitate was collected by filtration, washed with hexane $(10 \mathrm{~mL} \times 3)$, and dried up under vacuum to afford the product; 
Yield $1.10 \mathrm{~g}$ (3.74 mmol, 74.7\%);

Colorless solid (Hygroscopic);

${ }^{1} \mathrm{H}$ NMR (DMSO- $\left.d_{6}, 400 \mathrm{MHz}\right): \delta 9.18-9.16$ (AA'BB', 2H), 8.77-8.72 (m, 1H), 8.30-8.26 (AA'BB', 2H),

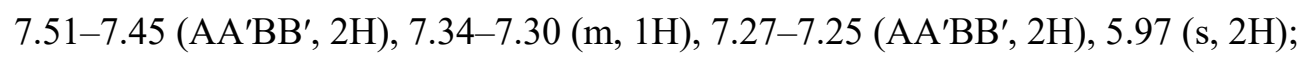

${ }^{13} \mathrm{C}\{1 \mathrm{H}\}$ NMR (DMSO- $\left.d_{6}, 100 \mathrm{MHz}\right): \delta 166.0(1 \mathrm{C}), 150.4(1 \mathrm{C}), 147.6(1 \mathrm{C}), 147.0(2 \mathrm{C}), 130.3(2 \mathrm{C}), 128.5$ (2C), 127.2 (1C), 121.9 (2C), 61.0 (1C);

IR $\left(\mathrm{ZnSe}, \mathrm{cm}^{-1}\right)$ 675, 758, 1177, 1188, 1206, 1487, 1765, 3030, 3412;

HRMS (ESI) $m / z$ : [M - Br] $]^{+}$Calcd for $\mathrm{C}_{13} \mathrm{H}_{12} \mathrm{NO}_{2}{ }^{+} 214.0863$; Found 214.0864.

2-Ethyl 3-phenyl indolizine-2,3-dicarboxylate (11)<smiles>CCOC(=O)c1cc2ccccn2c1C(=O)O</smiles>

1-(2-Oxo-2-phenoxyethyl)pyridin-1-ium bromide (S4, $589 \mathrm{mg}, 2.00 \mathrm{mmol}, 1$ equiv) and DMF (3.0 mL) were added into a $20 \mathrm{~mL}$ vial. The vial was filled with argon and set into an ice-water bath. A solution of ethyl propiolate (196 mg, $2.00 \mathrm{mmol}, 1.0$ equiv) in DMF $(1.0 \mathrm{~mL})$ was added into the vial dropwise. The resulting mixture was stirred for $4 \mathrm{~h}$. The reaction mixture was poured into a mixture of EtOAc $(15 \mathrm{~mL})$ and saturated aqueous $\mathrm{NaHCO}_{3}$ solution $(10 \mathrm{~mL})$, and extracted with EtOAc $(15 \mathrm{~mL} \times 3)$. The combined organic layer was dried with $\mathrm{Na}_{2} \mathrm{SO}_{4}$ and evaporated. The residue was purified by silica-gel column chromatography (hexane/EtOAc $=1 / 0$ to $0 / 1$ ) to afford the product;

Yield $15.1 \mathrm{mg}(48.8 \mu \mathrm{mol}, 2.44 \%)$;

Colorless solid (mp $121-123^{\circ} \mathrm{C}$ );

TLC $R \mathrm{f}=0.64(n$-hexane:EtOAc $=2: 1)$;

${ }^{1} \mathrm{H}$ NMR $\left(\mathrm{CDCl}_{3}, 400 \mathrm{MHz}\right): \delta 9.53-9.50(\mathrm{~m}, 1 \mathrm{H}), 8.42-8.39(\mathrm{~m}, 1 \mathrm{H}), 8.24(\mathrm{~s}, 1 \mathrm{H}), 7.47-7.35(\mathrm{~m}, 3 \mathrm{H}), 7.31-$ $7.23(\mathrm{~m}, 3 \mathrm{H}), 7.06-7.02(\mathrm{~m}, 1 \mathrm{H}), 4.41(\mathrm{q}, J=7.2 \mathrm{~Hz}, 2 \mathrm{H}), 1.44(\mathrm{t}, J=7.2 \mathrm{~Hz}, 3 \mathrm{H})$;

${ }^{13} \mathrm{C}\{1 \mathrm{H}\} \mathrm{NMR}\left(\mathrm{CDCl}_{3}, 100 \mathrm{MHz}\right): \delta 164.2(1 \mathrm{C}), 159.6(1 \mathrm{C}), 150.5(1 \mathrm{C}), 139.8(1 \mathrm{C}), 129.6(2 \mathrm{C}), 128.2(1 \mathrm{C})$, 126.4 (1C), 126.0 (1C), 125.6 (1C), 122.0 (2C), 119.8 (1C), 115.0 (1C), 113.7 (1C), 105.9 (1C), 60.2 (1C), $14.6(1 \mathrm{C})$;

IR $\left(\mathrm{ZnSe}, \mathrm{cm}^{-1}\right)$ 692, 743, 1022, 1136, 1186, 1481, 1682, 1709;

HRMS (ESI) $m / z$ : [M + H] $]^{+}$Calcd for $\mathrm{C}_{18} \mathrm{H}_{16} \mathrm{NO}_{4}{ }^{+} 310.1074$; Found 310.1072 .

1-(2-Ethoxy-2-oxoethyl)-2-methyl-5-(prop-2-yn-1-yloxy)pyridin-1-ium bromide (S5)<smiles>C#CCOc1ccc(C)[n+](CC(=O)OCC)c1</smiles>

Ethyl bromoacetate (1.09 g, $6.53 \mathrm{mmol}, 1.0$ equiv), THF (4.0 mL), and 2-methyl-5-(prop-2-yn-1yloxy)pyridine (957 mg, $6.50 \mathrm{mmol}, 1$ equiv) were added into a $20 \mathrm{~mL}$ vial. The resulting solution was stirred at $80^{\circ} \mathrm{C}$ for $12 \mathrm{~h}$ under argon atmosphere. After cooling to room temperature, the reaction mixture was poured into hexane $(50 \mathrm{~mL})$ to form a precipitate. The precipitate was collected by filtration, washed with hexane (10 
$\mathrm{mL} \times 3$ ), and dried up under vacuum to afford the product;

Yield $1.78 \mathrm{~g}(5.67 \mathrm{mmol}, 87.1 \%)$;

Colorless solid (mp $\left.151-154{ }^{\circ} \mathrm{C}\right)$;

${ }^{1} \mathrm{H}$ NMR (DMSO- $\left.d_{6}, 400 \mathrm{MHz}\right): \delta 8.96(\mathrm{~d}, J=2.8 \mathrm{~Hz}, 1 \mathrm{H}), 8.36(\mathrm{dd}, J=9.2,2.8 \mathrm{~Hz}, 1 \mathrm{H}), 8.11(\mathrm{~d}, J=9.2 \mathrm{~Hz}$, 1H), 5.66 (s, 2H), 5.10 (d, $J=2.4 \mathrm{~Hz}, 2 \mathrm{H}), 4.25(\mathrm{q}, 7.2 \mathrm{~Hz}, 2 \mathrm{H}), 3.82(\mathrm{t}, J=2.4 \mathrm{~Hz}, 1 \mathrm{H}), 2.67(\mathrm{~s}, 3 \mathrm{H}), 1.25$ (t, $J=7.2 \mathrm{~Hz}, 3 \mathrm{H})$;

${ }^{13} \mathrm{C}\{1 \mathrm{H}\}$ NMR (DMSO-d, $\left.100 \mathrm{MHz}\right): \delta 166.2(1 \mathrm{C}), 154.4(1 \mathrm{C}), 149.6(1 \mathrm{C}), 135.6(1 \mathrm{C}), 133.4(1 \mathrm{C}), 130.6$ (1C), 80.9 (1C), 77.7 (1C), 63.1 (1C), 58.7 (1C), 58.0 (1C), 19.1 (1C), 14.4 (1C);

IR $\left(\mathrm{ZnSe}, \mathrm{cm}^{-1}\right)$ 847, 1009, 1207, 1229, 1288, 1530, 1746, 2992, 3173;

HRMS (ESI) $m / z$ : $[\mathrm{M}-\mathrm{Br}]^{+}$Calcd for $\mathrm{C}_{13} \mathrm{H}_{16} \mathrm{NO}_{3}{ }^{+}$234.1125; Found 234.1125.

2-Methoxy-6-(prop-2-yn-1-yloxy)indolizine (S6)

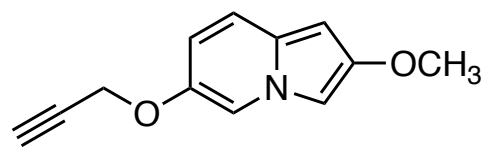

1-(2-Ethoxy-2-oxoethyl)-2-methyl-5-(prop-2-yn-1-yloxy)pyridin-1-ium bromide (S5, 1.26 g, 4.01 mmol, 1.0 equiv), DMF $(20 \mathrm{~mL})$, and $i-\mathrm{PrOH}(20 \mathrm{~mL})$ were added into a $300 \mathrm{~mL}$ round-bottom flask. The flask was filled with argon and set into an ice water bath. Cesium hydroxide monohydrate (1.34 g, $7.98 \mathrm{mmol}, 2.0$ equiv) was added to the solution in one portion. The resulting mixture was stirred at room temperature for $30 \mathrm{~min}$. Then, dimethyl sulfate ( $379 \mu \mathrm{L}, 4.00 \mathrm{mmol}, 1$ equiv) was added dropwise to the mixture over $5 \mathrm{~min}$ at room temperature, and the mixture was further stirred at room temperature for $2 \mathrm{~h}$. The mixture was then poured into a solution of hexane $(150 \mathrm{~mL})$ and EtOAc $(75 \mathrm{~mL})$, and washed with brine $(200 \mathrm{~mL} \times 3)$. The organic layer was dried with sodium sulfate and evaporated. The residue was purified by silica-gel column chromatography (hexane/EtOAc $=1 / 0$ to $3 / 1$ ) to afford the product;

Yield $89.5 \mathrm{mg}(0.445 \mathrm{mmol}, 11.1 \%)$;

Colorless solid (mp $\left.83-84^{\circ} \mathrm{C}\right)$;

TLC $R \mathrm{f}=0.35(n$-hexane:EtOAc $=3: 1)$;

${ }^{1} \mathrm{H} \mathrm{NMR}\left(\mathrm{CDCl}_{3}, 400 \mathrm{MHz}\right): \delta 7.59-7.58(\mathrm{~m}, 1 \mathrm{H}), 7.14(\mathrm{~d}, J=9.6 \mathrm{~Hz}, 1 \mathrm{H}), 6.96(\mathrm{~d}, J=1.2 \mathrm{~Hz}, 1 \mathrm{H}), 6.55(\mathrm{dd}$, $J=9.6,2.4 \mathrm{~Hz}, 1 \mathrm{H}), 6.04(\mathrm{~s}, 1 \mathrm{H}), 4.62(\mathrm{~d}, J=2.4 \mathrm{~Hz}, 2 \mathrm{H}), 3.83(\mathrm{~s}, 3 \mathrm{H}), 2.55(\mathrm{t}, J=2.4 \mathrm{~Hz}, 1 \mathrm{H})$;

${ }^{13} \mathrm{C}\{1 \mathrm{H}\} \mathrm{NMR}\left(\mathrm{CDCl}_{3}, 100 \mathrm{MHz}\right): \delta 152.8(1 \mathrm{C}), 145.4(1 \mathrm{C}), 128.5(1 \mathrm{C}), 118.3(1 \mathrm{C}), 112.8(1 \mathrm{C}), 110.6(1 \mathrm{C})$, 98.0 (1C), 85.9 (1C), 78.4 (1C), 76.1 (1C), 57.8 (1C), 57.7 (1C);

IR $\left(\mathrm{ZnSe}, \mathrm{cm}^{-1}\right)$ 698, 781, 1011, 1169, 1348, 1518, 1555, 3275;

HRMS (ESI) m/z: [M+ H] $]^{+}$Calcd for $\mathrm{C}_{12} \mathrm{H}_{12} \mathrm{NO}_{2}{ }^{+}$202.0863; Found 202.0863.

Phenyl 2-methoxy-6-(prop-2-yn-1-yloxy)indolizine-3-carboxylate (12)<smiles>C#CCOc1ccc2cc(OC)c(C(=O)O)n2c1</smiles>

2-Methoxy-6-(prop-2-yn-1-yloxy)indolizine ( $\mathbf{S 6}, 30.2 \mathrm{mg}, 0.150 \mathrm{mmol}, 1$ equiv) and THF (0.75 $\mathrm{mL})$ were 
added into a $4 \mathrm{~mL}$ vial. The vial was filled with argon and set into an ice-water bath. A solution of phenyl chloroformate $(25.8 \mathrm{mg}, 0.165 \mathrm{mmol}, 1.1$ equiv) in THF $(0.75 \mathrm{~mL})$ was added into the vial dropwise. The resulting mixture was stirred at room temperature for $4 \mathrm{~h}$. The reaction mixture was then poured into a mixture of EtOAc $(15 \mathrm{~mL})$ and saturated aqueous $\mathrm{NaHCO}_{3}$ solution $(10 \mathrm{~mL})$, and extracted with EtOAc $(15 \mathrm{~mL} \times 3)$. The combined organic layer was dried with $\mathrm{Na}_{2} \mathrm{SO}_{4}$ and evaporated. The residue was purified by silica-gel column chromatography (hexane/EtOAc $=1 / 0$ to $1 / 1$ ) to afford the product;

Yield $22.5 \mathrm{mg}(70.0 \mu \mathrm{mol}, 46.7 \%)$;

Colorless solid (mp $127-128^{\circ} \mathrm{C}$ );

TLC $R \mathrm{f}=0.50(n$-hexane:EtOAc $=2: 1)$;

${ }^{1} \mathrm{H} \mathrm{NMR}\left(\mathrm{CDCl}_{3}, 400 \mathrm{MHz}\right): \delta 9.29(\mathrm{~d}, J=2.4 \mathrm{~Hz}, 1 \mathrm{H}), 7.44-7.40(\mathrm{~m}, 2 \mathrm{H}), 7.31-7.23(\mathrm{~m}, 4 \mathrm{H}), 6.97(\mathrm{dd}, J=$ 9.6, 7.6 Hz, 1H), 6.07 (s, 1H), $4.67(\mathrm{~d}, J=2.4 \mathrm{~Hz}, 2 \mathrm{H}), 3.99$ (s, 3H), $2.54(\mathrm{t}, J=2.4 \mathrm{~Hz}, 1 \mathrm{H})$;

${ }^{13} \mathrm{C}\{1 \mathrm{H}\} \mathrm{NMR}\left(\mathrm{CDCl}_{3}, 100 \mathrm{MHz}\right): \delta 160.3(1 \mathrm{C}), 158.0(1 \mathrm{C}), 150.9(1 \mathrm{C}), 147.0(1 \mathrm{C}), 133.9(1 \mathrm{C}), 129.4(2 \mathrm{C})$, 125.5 (1C), 122.5 (2C), 118.7 (1C), 117.5 (1C), 112.9 (1C), 101.9 (1C), 85.4 (1C), 77.8 (1C), 76.3 (1C), 58.2 (1C), $57.1(1 \mathrm{C})$;

IR $\left(\mathrm{ZnSe}, \mathrm{cm}^{-1}\right) 673,858,1022,1094,1190,1265,1422,1670,3260$;

HRMS (ESI) $m / z$ : [M + H $]^{+}$Calcd for $\mathrm{C}_{19} \mathrm{H}_{16} \mathrm{NO}_{4}{ }^{+}$322.1074; Found 322.1073.

4-Methyl-2-oxo-2H-chromen-7-yl 2-methoxy-6-(prop-2-yn-1-yloxy)indolizine-3-carboxylate (15)

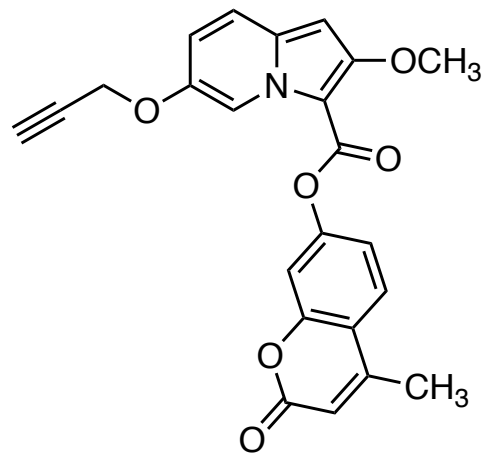

2-Methoxy-6-(prop-2-yn-1-yloxy)indolizine (S6, $40.2 \mathrm{mg}, 0.200 \mathrm{mmol}, 1$ equiv) and $\mathrm{CH}_{2} \mathrm{Cl}_{2}(0.75 \mathrm{~mL})$ were added into a $4 \mathrm{~mL}$ vial. The vial was filled with argon and set into an ice-water bath. A solution of 4methyl-2-oxo-2H-chromen-7-yl carbonochloridate ( $71.6 \mathrm{mg}, 0.300 \mathrm{mmol}, 1.5$ equiv) in $\mathrm{CH}_{2} \mathrm{Cl}_{2}(0.75 \mathrm{~mL}$ ) was added into the vial dropwise. The resulting mixture was stirred at room temperature for $4 \mathrm{~h}$. The mixture was then poured into a mixture of EtOAc $(15 \mathrm{~mL})$ and saturated aqueous $\mathrm{NaHCO}_{3}$ solution $(10 \mathrm{~mL})$, and extracted with EtOAc $(15 \mathrm{~mL} \times 3)$. The combined organic layer was dried with $\mathrm{Na}_{2} \mathrm{SO}_{4}$ and evaporated. The residue was purified by silica-gel column chromatography (hexane/EtOAc $=1 / 0$ to $1 / 1$ ). The product was further purified by GPC (YMC-GPC T2000, $21.2 \times 600 \mathrm{~mm}$, chloroform) to afford the product;

Yield $50.2 \mathrm{mg}(0.124 \mathrm{mmol}, 62.3 \%)$;

Colorless solid (mp $172-175^{\circ} \mathrm{C}$ );

TLC $R \mathrm{f}=0.43(n$-hexane:EtOAc $=1: 1)$;

${ }^{1} \mathrm{H} \mathrm{NMR}\left(\mathrm{CDCl}_{3}, 400 \mathrm{MHz}\right): \delta 9.27(\mathrm{~d}, J=2.0 \mathrm{~Hz}, 1 \mathrm{H}), 7.65(\mathrm{~d}, J=8.8 \mathrm{~Hz}, 1 \mathrm{H}), 7.33-7.23(\mathrm{~m}, 3 \mathrm{H}), 7.01$ (dd, $J=9.6,2.0 \mathrm{~Hz}, 1 \mathrm{H}), 6.27(\mathrm{~d}, J=1.6 \mathrm{~Hz}, 1 \mathrm{H}), 6.07(\mathrm{~s}, 1 \mathrm{H}), 4.69(\mathrm{~d}, J=2.4 \mathrm{~Hz}, 2 \mathrm{H}), 4.00(\mathrm{~s}, 3 \mathrm{H}), 2.56(\mathrm{t}, J=$ $2.4 \mathrm{~Hz}, 1 \mathrm{H}), 2.46$ (s, 3H); 
${ }^{13} \mathrm{C}\{1 \mathrm{H}\} \mathrm{NMR}\left(\mathrm{CDCl}_{3}, 100 \mathrm{MHz}\right): \delta 160.9(1 \mathrm{C}) ; 159.3(1 \mathrm{C}), 158.2(1 \mathrm{C}), 154.3(1 \mathrm{C}), 153.7(1 \mathrm{C}), 152.2(1 \mathrm{C})$, 147.2 (1C), $134.4(1 \mathrm{C}), 125.2$ (1C), 119.2 (1C), 119.1 (1C), 117.6 (1C), 117.5 (1C), 114.3 (1C), 113.0 (1C), 111.3 (1C), 101.4 (1C), 85.6 (1C), 77.7 (1C), 76.5 (1C), 58.2 (1C), 57.2 (1C), 18.9 (1C);

IR $\left(\mathrm{ZnSe}, \mathrm{cm}^{-1}\right)$ 1007, 1094, 1132, 1261, 1462, 1674, 1724, 3283;

HRMS (ESI) $m / z$ : $[\mathrm{M}+\mathrm{H}]^{+}$Calcd for $\mathrm{C}_{23} \mathrm{H}_{18} \mathrm{NO}_{6}{ }^{+}$404.1129; Found 404.1129.

Insulin-indolizine-4-methylumbellifenone conjugate $\mathbf{1 3}$

A solution of copper(II) sulfate pentahydrate $(2.6 \mathrm{mg}, 10 \mu \mathrm{mol}, 3.0$ equiv) in water (100 $\mu \mathrm{L})$, a solution of tris((1-benzyl-1H-1,2,3-triazol-4-yl)methyl)amine (TBTA) $(5.4 \mathrm{mg}, 10 \mu \mathrm{mol}, 3.0$ equiv) in DMSO $(350 \mu \mathrm{L})$, and a solution of sodium L-ascorbate $(2.6 \mathrm{mg}, 14 \mu \mathrm{mol}, 4.0$ equiv) in water $(50 \mu \mathrm{L})$ were combined. The mixed solution was added to a solution of triazidoinsulin (14, $20.0 \mathrm{mg}, 3.40 \mu \mathrm{mol}, 1$ equiv) and 4-methyl-2-oxo- $2 \mathrm{H}$ chromen-7-yl 2-methoxy-6-(prop-2-yn-1-yloxy)indolizine-3-carboxylate (15, $6.9 \mathrm{mg}, 17 \mu \mathrm{mol}, 5$ equiv) in DMSO $(1.5 \mathrm{~mL})$ in a $4 \mathrm{~mL}$ vial. The resulting solution was stirred at room temperature for $6 \mathrm{~h}$ under argon atmosphere. The solution was then passed through a $0.21 \mu \mathrm{m}$ syringe filter and purified by HPLC (COSMOSIL $\mathrm{C}_{18}$-AR-II, $10 \times 250 \mathrm{~mm} ; \mathrm{H}_{2} \mathrm{O} /$ acetonitrile $+0.1 \mathrm{v} / \mathrm{v} \%$ trifluoroacetic acid, $95 / 5$ to $\left.5 / 95\right)$. The eluent was freezedried to afford the product;

Yield $16.9 \mathrm{mg}(2.38 \mu \mathrm{mol}, 70.0 \%)$;

HRMS (ESI) $m / z$ : M (deconvoluted) Calcd for $\mathrm{C}_{326} \mathrm{H}_{428} \mathrm{~N}_{74} \mathrm{O}_{95} \mathrm{~S}_{6}$ 7090.9259; Found 7090.9038; Difference $0.0221(3.12 \mathrm{ppm})$;

HPLC $R_{\mathrm{t}} 22.6 \mathrm{~min}$ (COSMOSIL C 18 -AR-II, $10 \times 250 \mathrm{~mm} ; \mathrm{H}_{2} \mathrm{O} /$ acetonitrile $+0.1 \mathrm{v} / \mathrm{v} \%$ trifluoroacetic acid, $95 / 5$ to $5 / 95,30 \mathrm{~min}$ with a flow rate of $5.0 \mathrm{~mL} / \mathrm{min}$ ). 


\section{References for Supporting Information}

(S1) Joshi, M. C.; Joshi, P.; Rawat, D. S. ARKIVOC 2006, 16, 65-74.

(S2) Hynd, G.; Ray, N. C.; Finch, H.; Montana, J. G.; Cramp, M. C.; Harrison, T. K.; Arienzo, R.; Blaney, P.; Griffon, Y.; Middlemiss, D. PCT Int. Appl. 2007, WO 2007031747.

(S3) Hu, X.; Zeng, T.; Husic, C. C.; Robb, M. J. J. Am. Chem. Soc. 2019, 141, 15018-15023.

(S4) Boga, S. B.; Krska, S. W.; Lin, S. N.; Pissarnitski, D.; Yan, L.; Kekec, A.; Tang, W. J.; Pierson, N. A.; Strulson, C. A.; Streckfuss, E.; Zhu, X. H.; Zhang, X. P.; Kelly, T.; Parish, C. A. Bioconjugate Chem. 2019, 30, 1127-1132.

(S5) Robert, S. L.; Lawrence, R.; Williams, J. M. J.; Bull, S. D. Org. Lett. 2017, 19, 4908-4911.

(S6) Kakehi, A.; Ito, S.; Watanabe, K.; Kitagawa, M.; Takeuchi, S.; Hashimoto, T. J. Org. Chem. 1980, 45, $5100-5104$. 


\section{NMR spectra and HPLC chart}

${ }^{1} \mathrm{H}$ NMR $(400 \mathrm{MHz})$ and ${ }^{13} \mathrm{C}$ NMR $(100 \mathrm{MHz})$ spectra of $\mathbf{S 1}\left(\mathrm{CDCl}_{3}\right)$
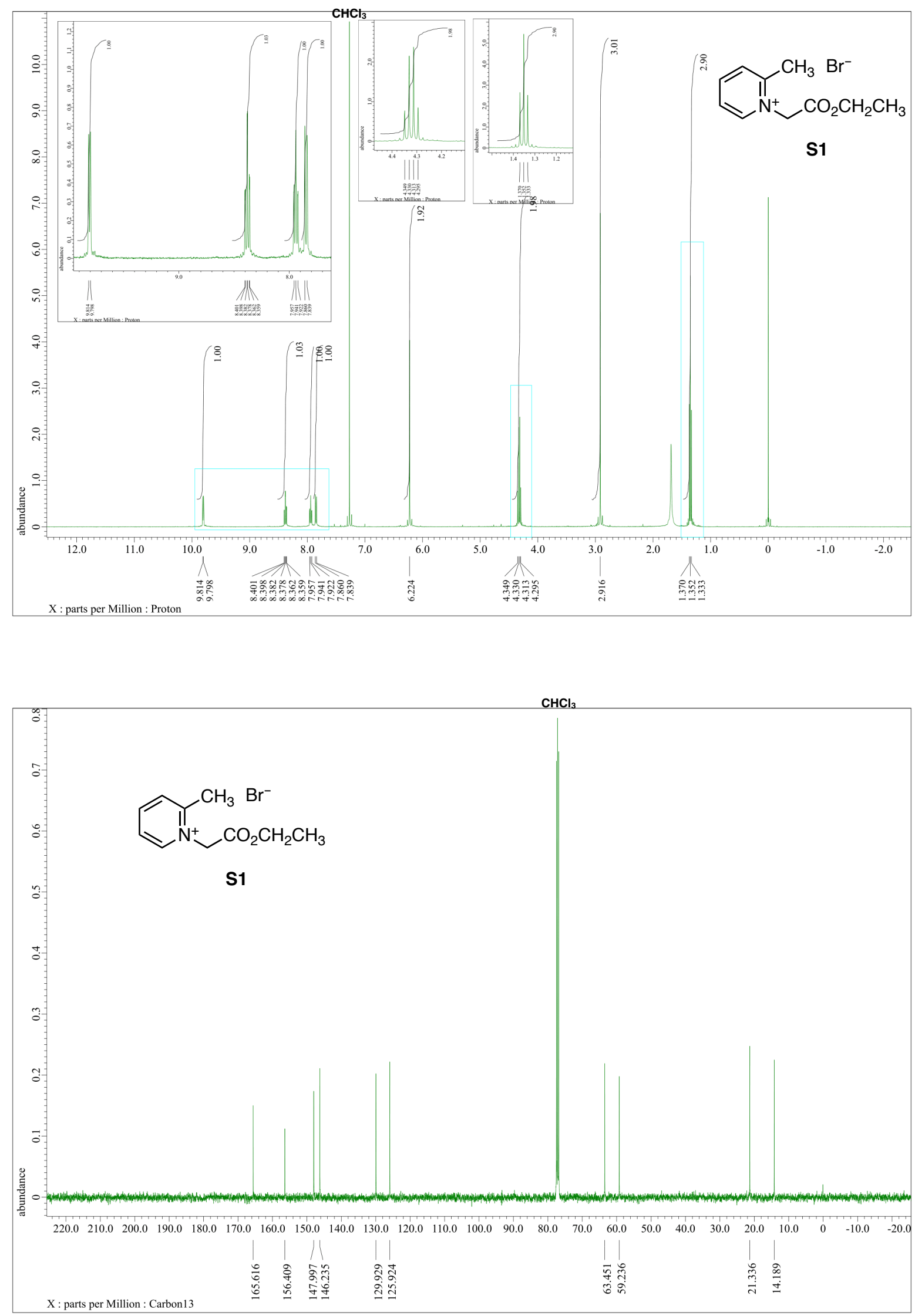
${ }^{1} \mathrm{H}$ NMR $(400 \mathrm{MHz})$ and ${ }^{13} \mathrm{C}$ NMR $(100 \mathrm{MHz})$ spectra of $\mathbf{S 2}\left(\mathrm{CDCl}_{3}\right)$
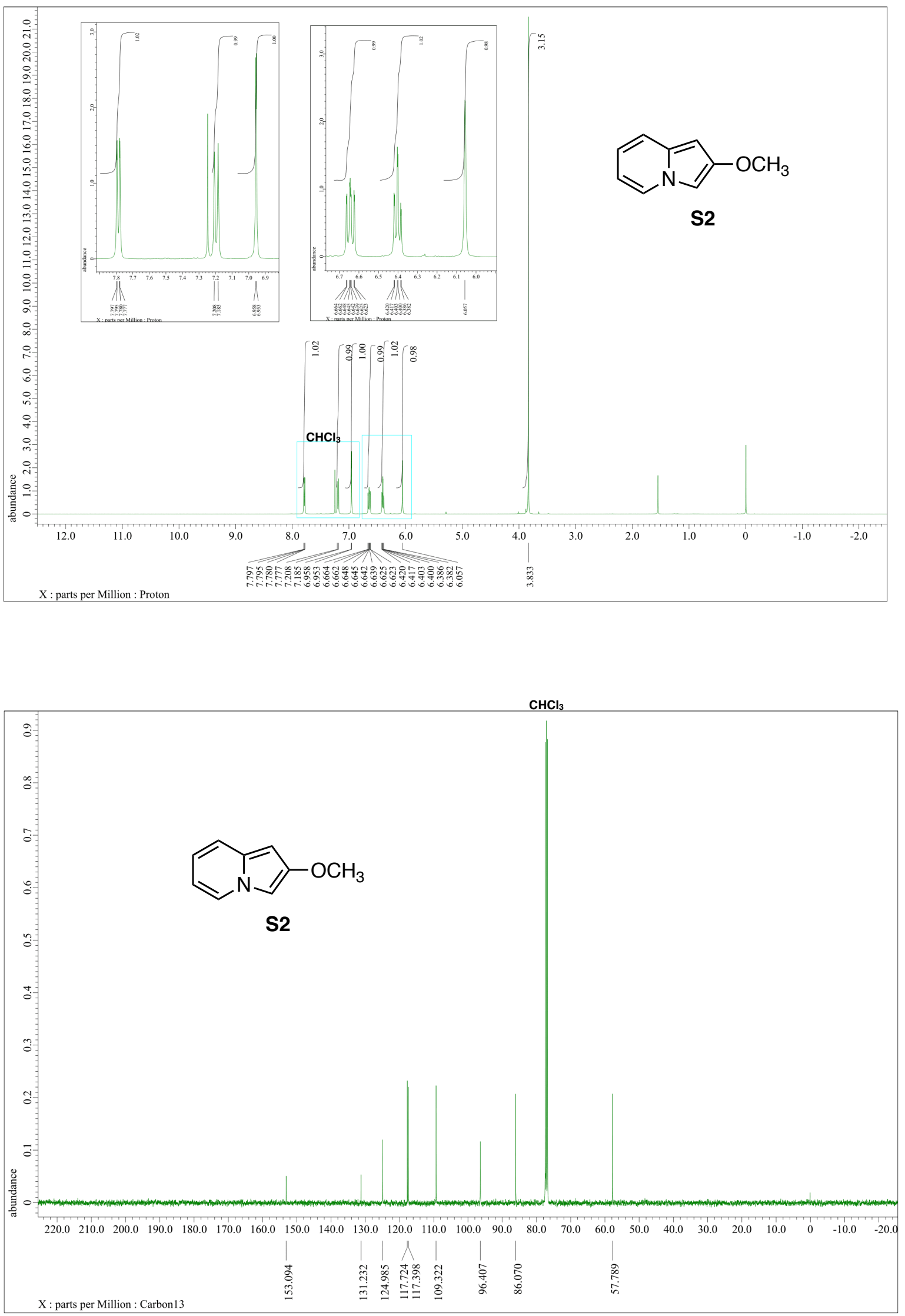
${ }^{1} \mathrm{H}$ NMR (400 MHz) and ${ }^{13} \mathrm{C}$ NMR (100 MHz) spectra of $1\left(\mathrm{CDCl}_{3}\right)$
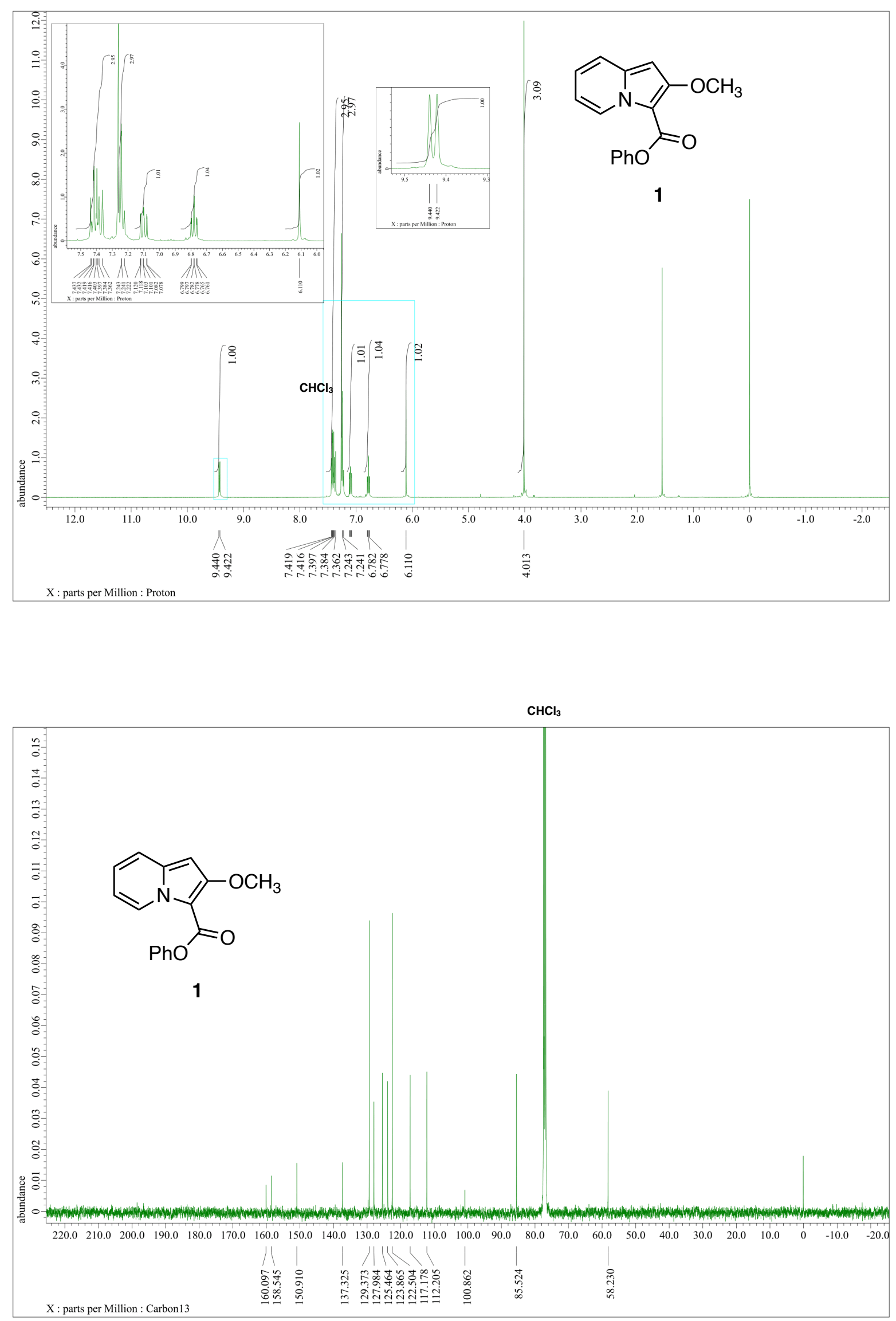
${ }^{1} \mathrm{H}$ NMR (400 MHz) and ${ }^{13} \mathrm{C}$ NMR $(100 \mathrm{MHz})$ spectra of $\mathbf{3}\left(\mathrm{CDCl}_{3}\right)$
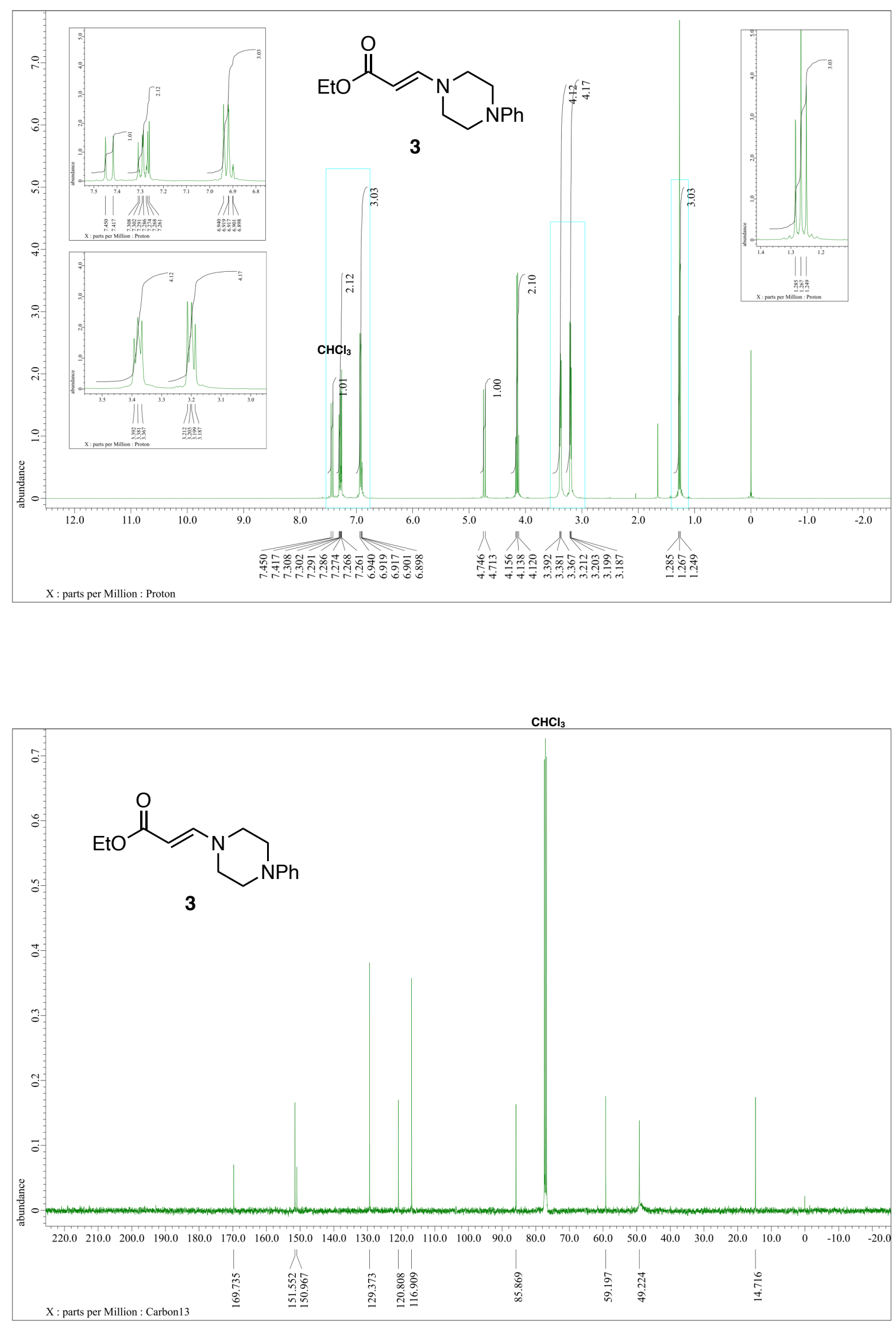
${ }^{1} \mathrm{H}$ NMR $(400 \mathrm{MHz})$ and ${ }^{13} \mathrm{C}$ NMR $(100 \mathrm{MHz})$ spectra of $4\left(\mathrm{CDCl}_{3}\right)$
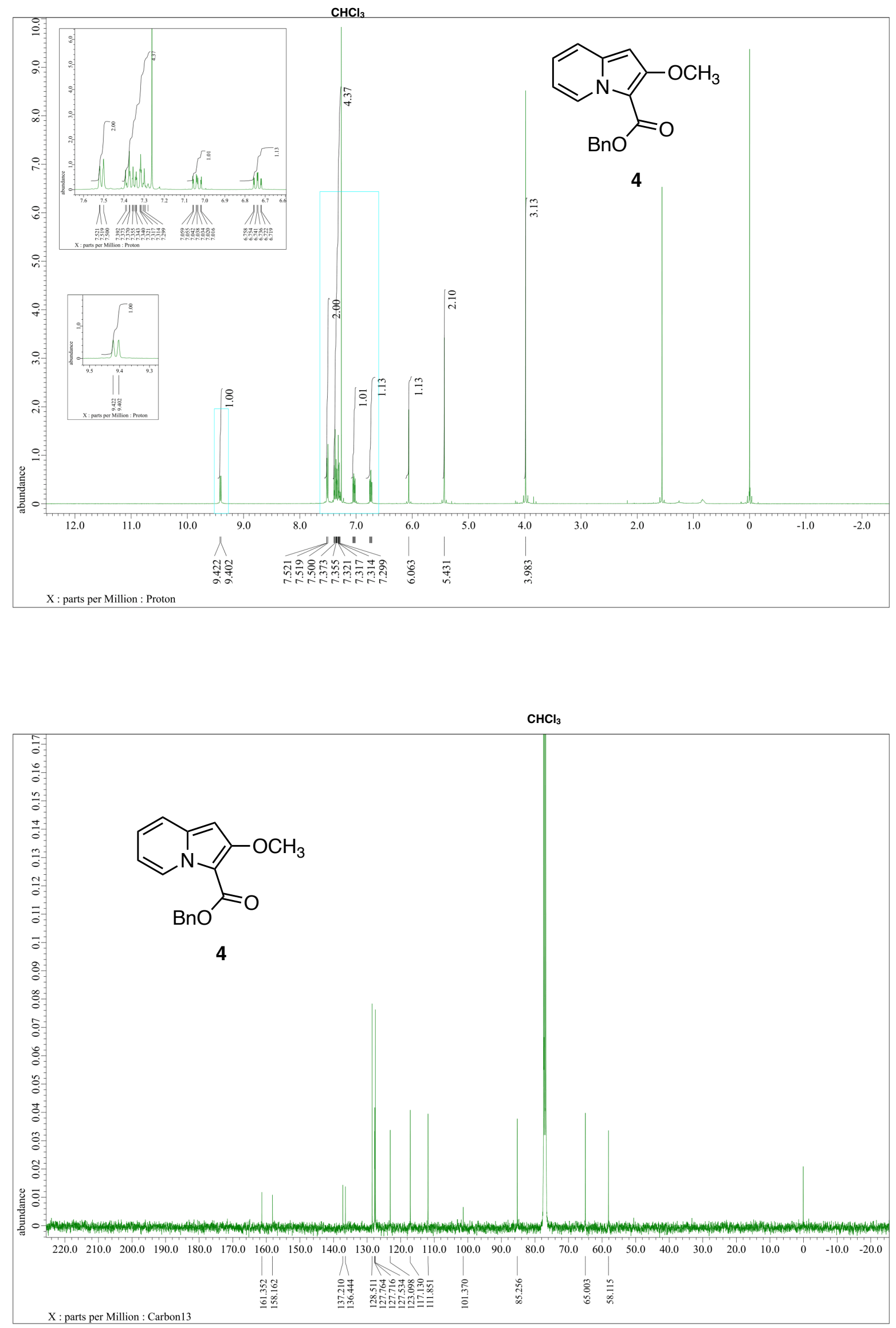
${ }^{1} \mathrm{H}$ NMR (400 MHz) and ${ }^{13} \mathrm{C}$ NMR (100 MHz) spectra of $5\left(\mathrm{CDCl}_{3}\right)$
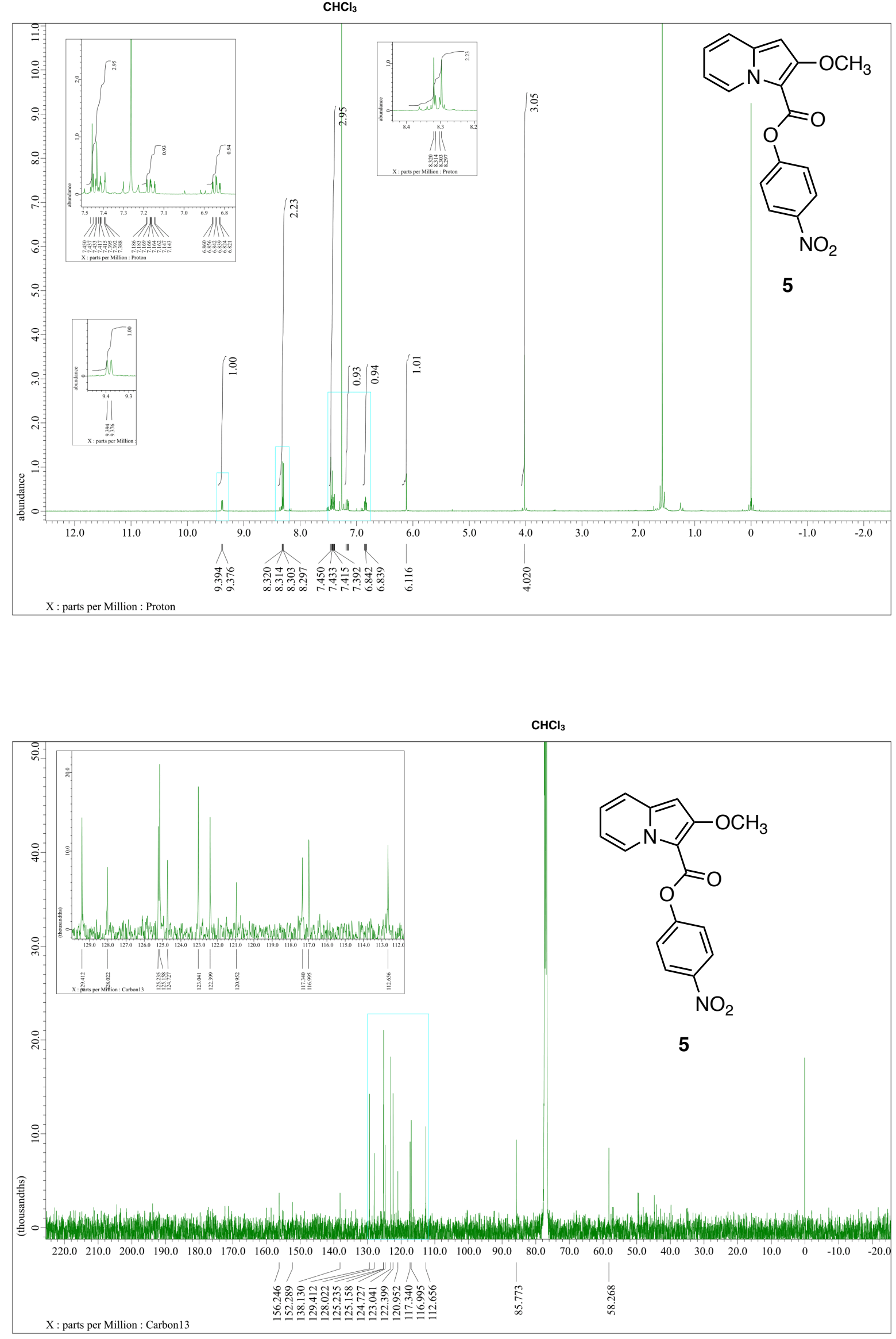
${ }^{1} \mathrm{H}$ NMR $(400 \mathrm{MHz})$ and ${ }^{13} \mathrm{C}$ NMR $(100 \mathrm{MHz})$ spectra of $\mathbf{6}\left(\mathrm{CDCl}_{3}\right)$
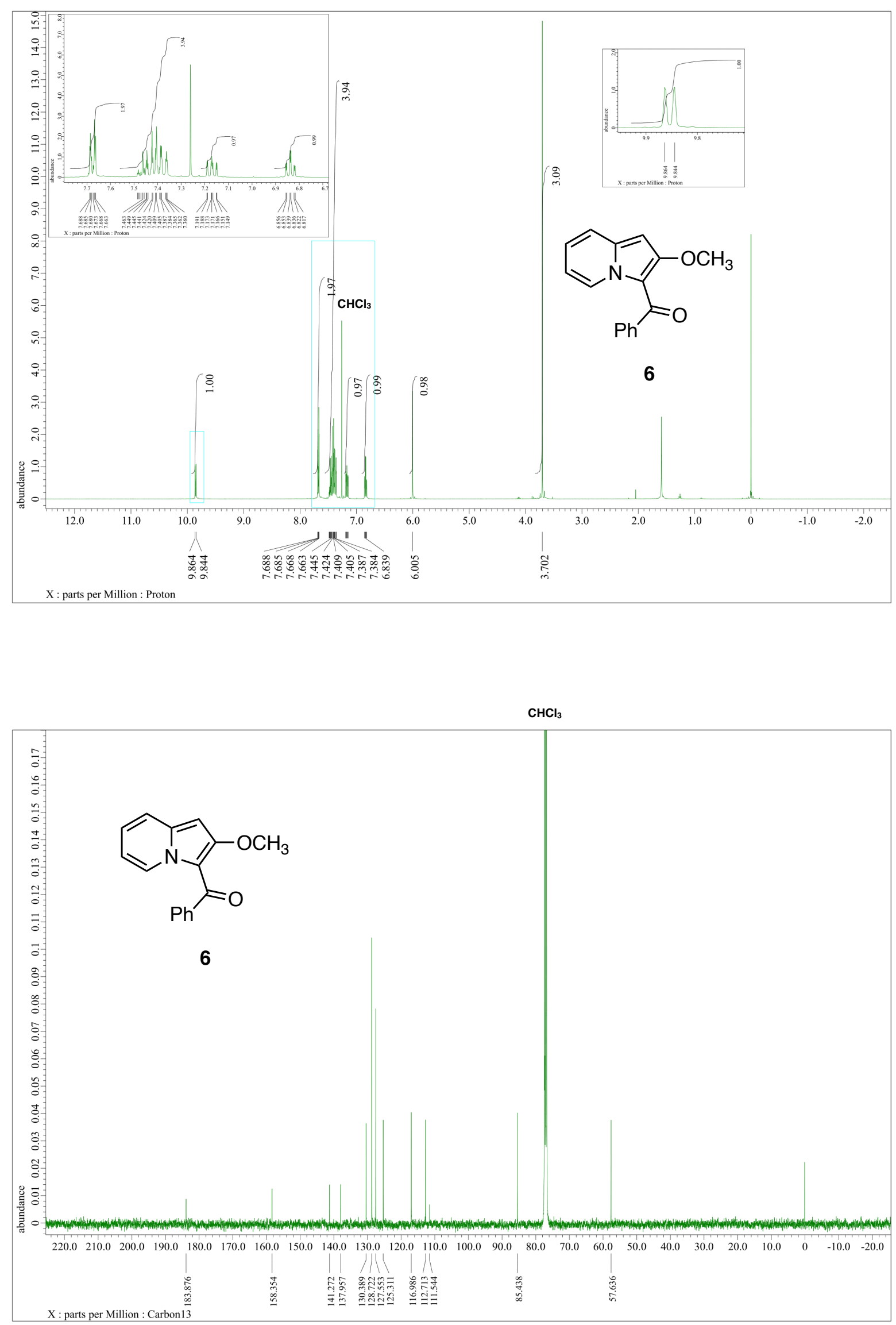
${ }^{1} \mathrm{H}$ NMR (400 MHz) and ${ }^{13} \mathrm{C}$ NMR $(100 \mathrm{MHz})$ spectra of $7\left(\mathrm{CDCl}_{3}\right)$
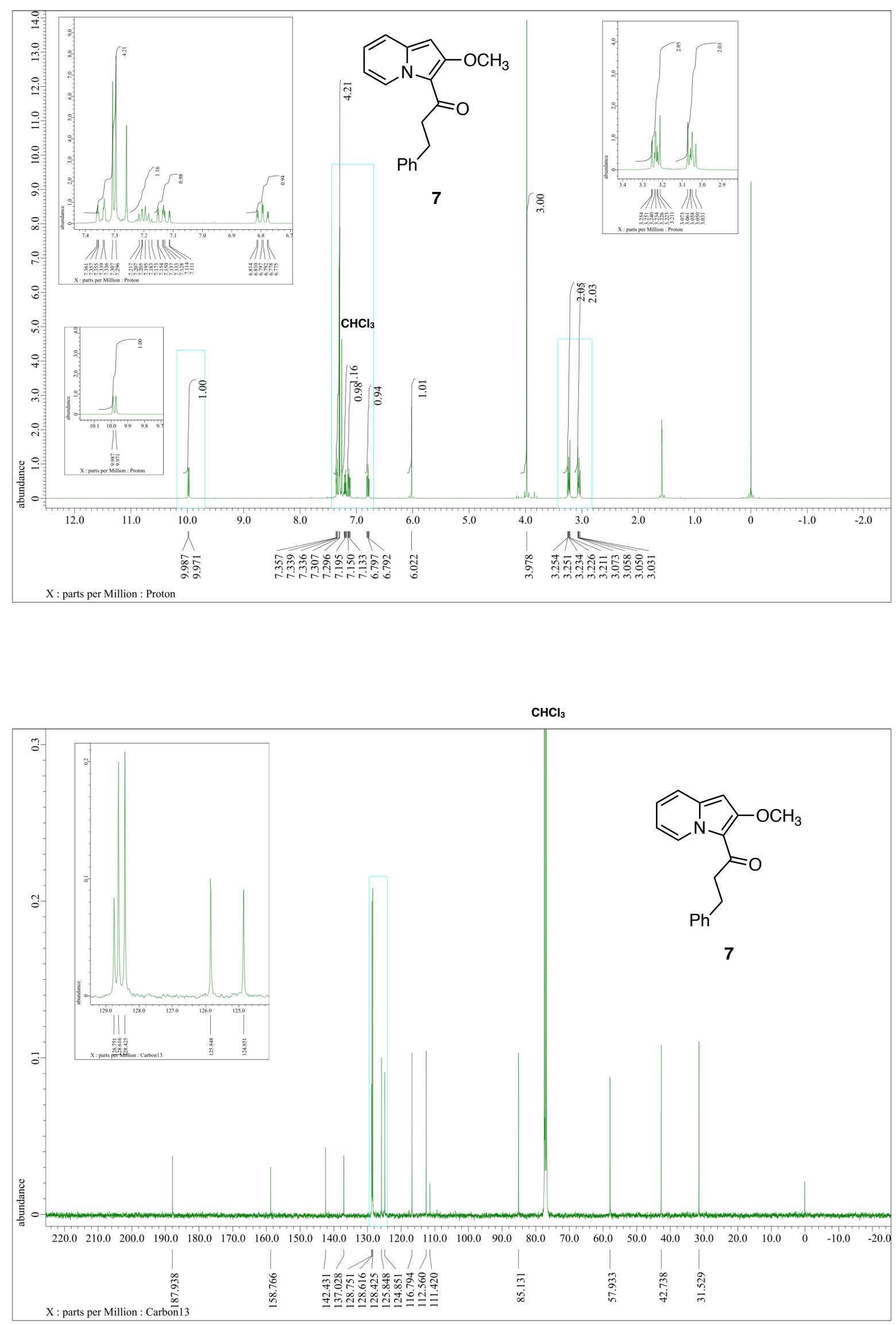
${ }^{1} \mathrm{H}$ NMR $(400 \mathrm{MHz})$ and ${ }^{13} \mathrm{C}$ NMR $(100 \mathrm{MHz})$ spectra of $8\left(\mathrm{CDCl}_{3}\right)$
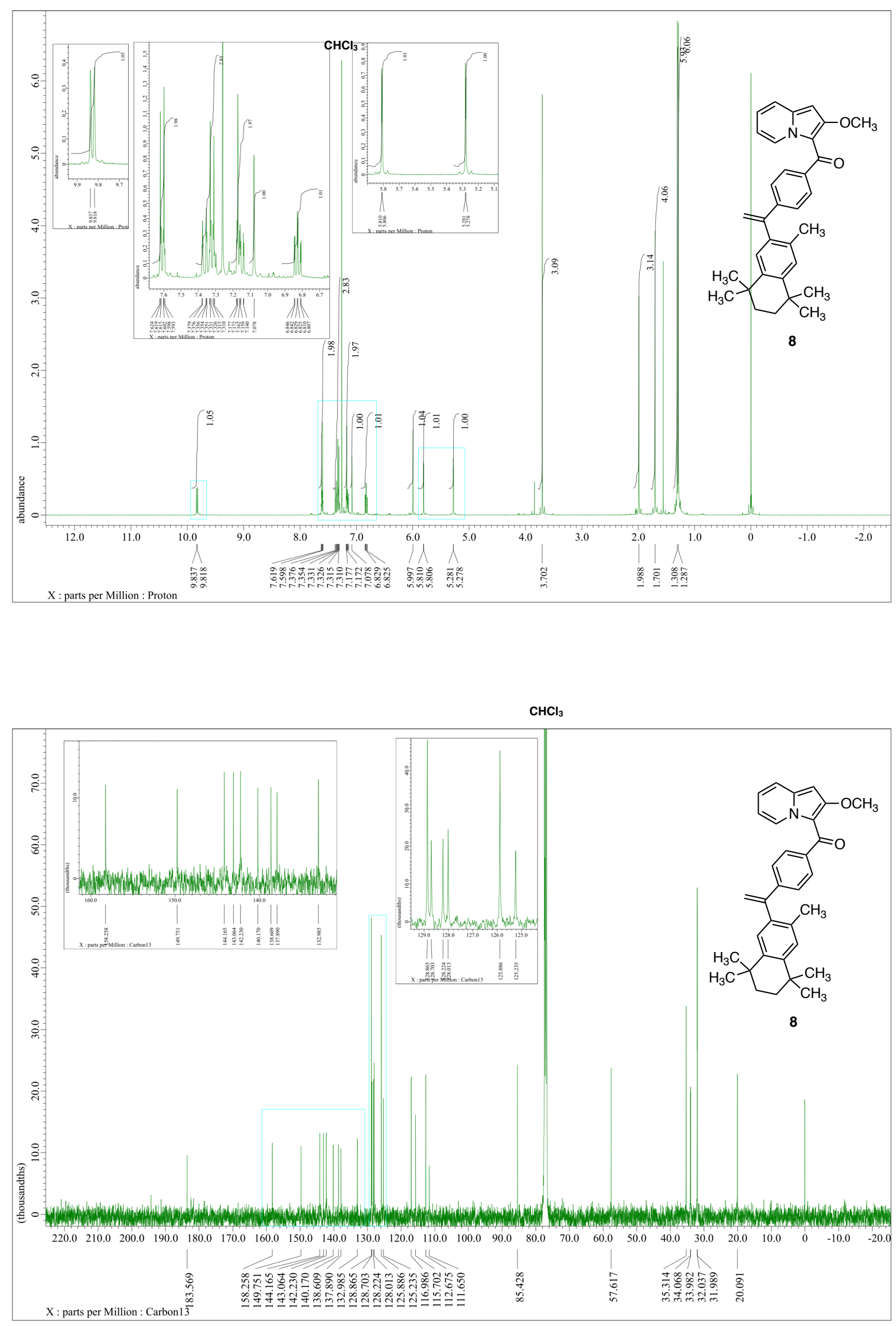
${ }^{1} \mathrm{H}$ NMR $(400 \mathrm{MHz})$ and ${ }^{13} \mathrm{C}$ NMR $(100 \mathrm{MHz})$ spectra of $9\left(\mathrm{CDCl}_{3}\right)$
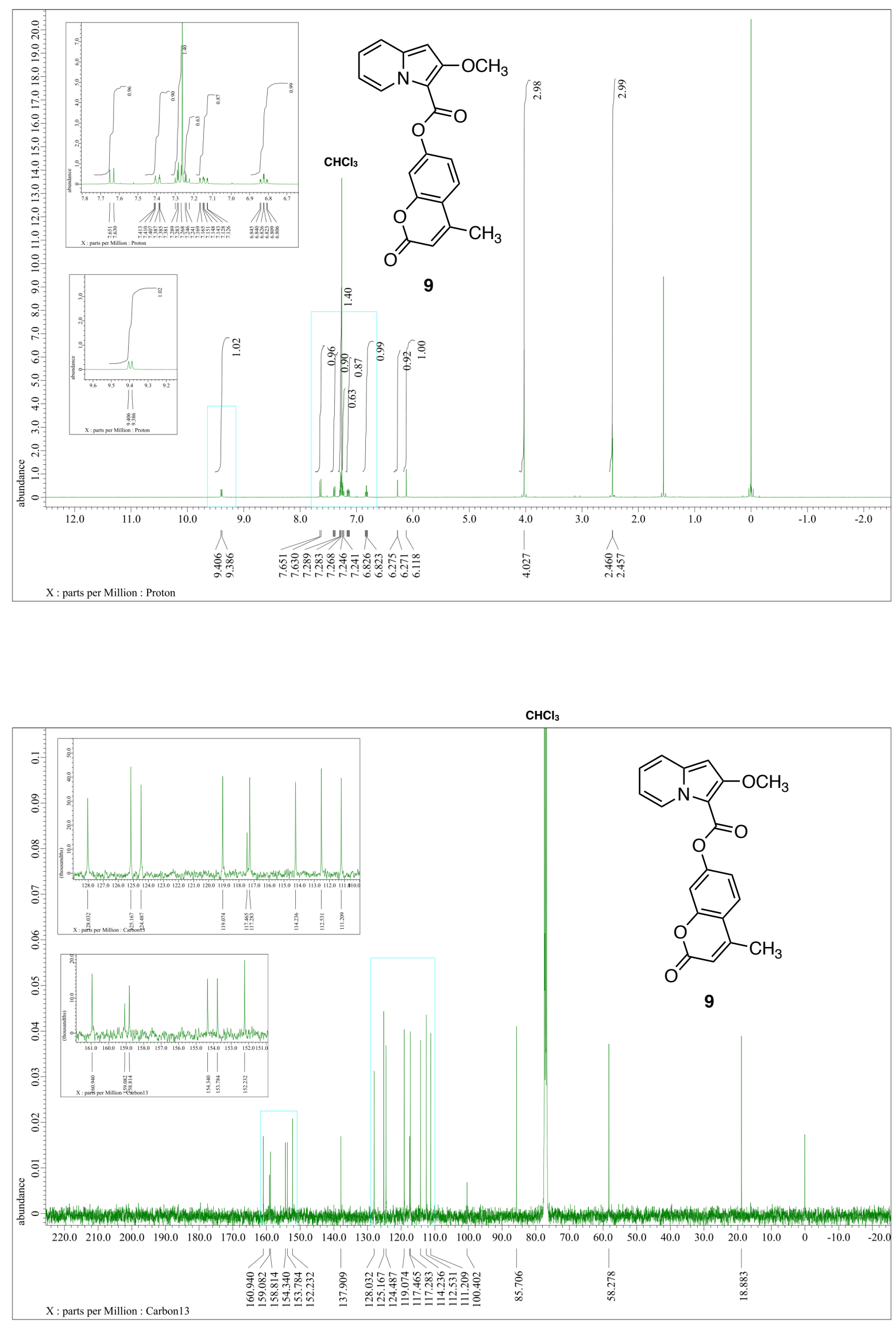
${ }^{1} \mathrm{H}$ NMR (400 MHz) and ${ }^{13} \mathrm{C}$ NMR $(100 \mathrm{MHz})$ spectra of $\mathbf{1 0}\left(\mathrm{CDCl}_{3}\right)$
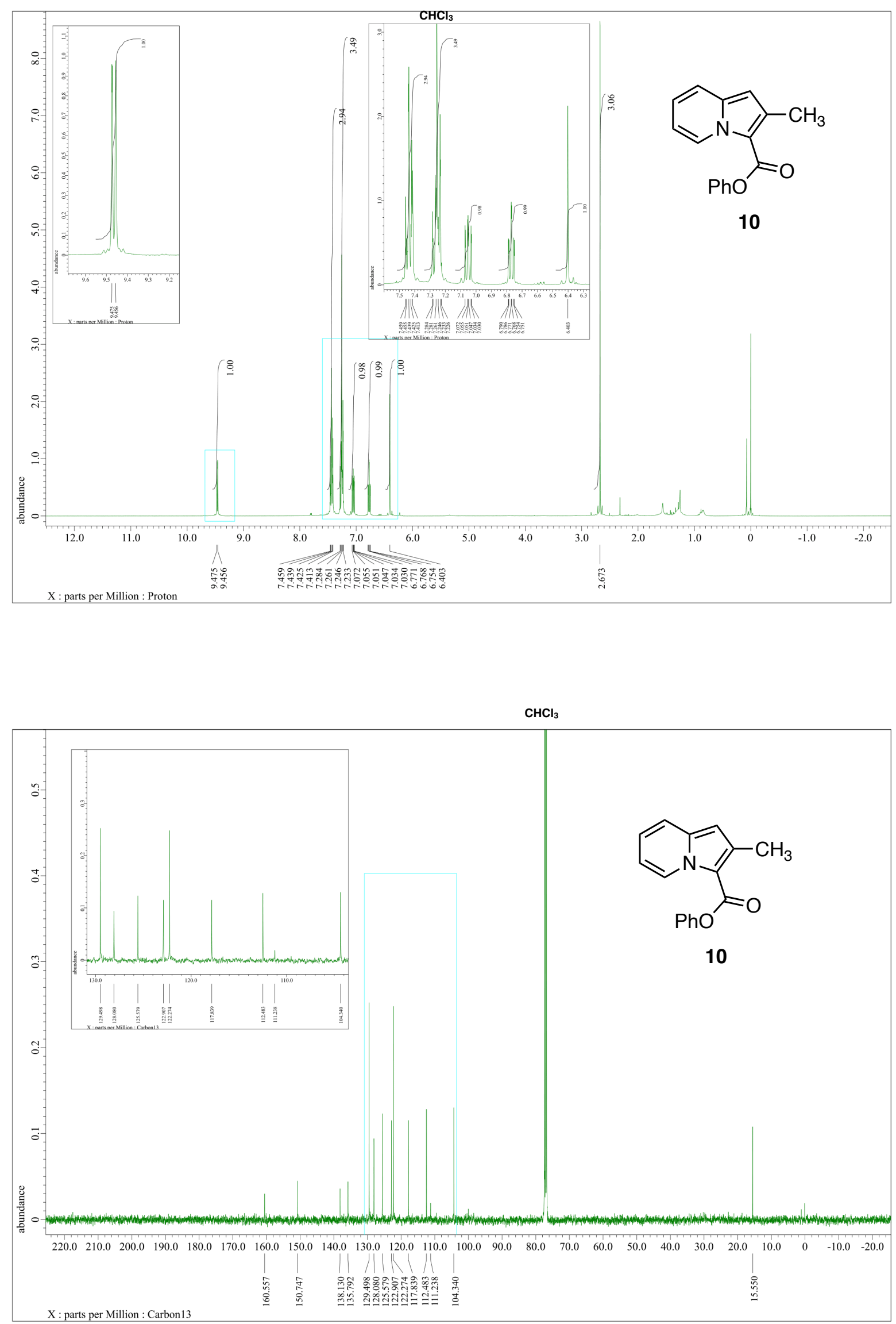
${ }^{1} \mathrm{H}$ NMR (400 MHz) and ${ }^{13} \mathrm{C}$ NMR (100 MHz) spectra of S4 (DMSO- $d_{6}$ )
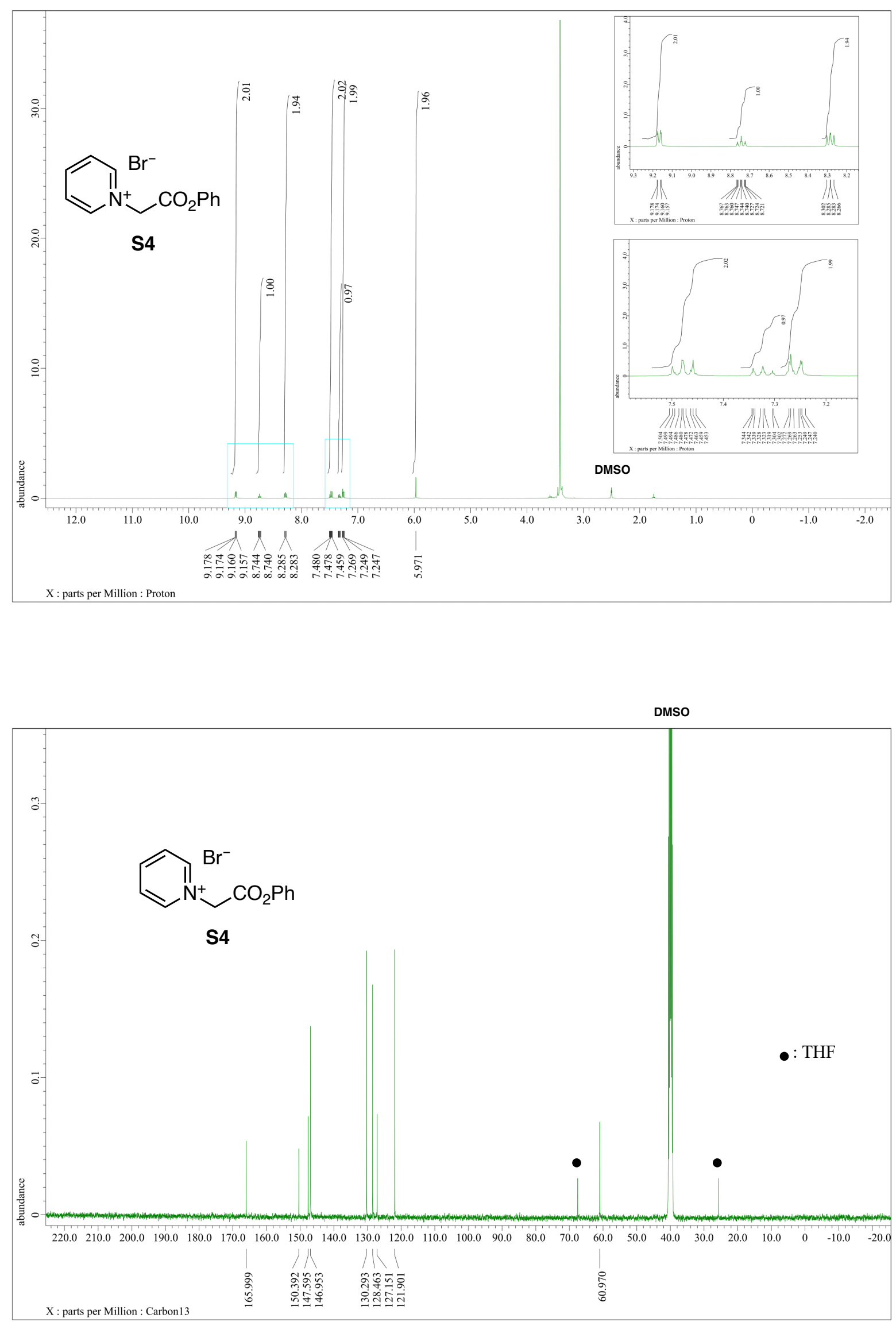
${ }^{1} \mathrm{H}$ NMR (400 MHz) and ${ }^{13} \mathrm{C}$ NMR $(100 \mathrm{MHz})$ spectra of $11\left(\mathrm{CDCl}_{3}\right)$
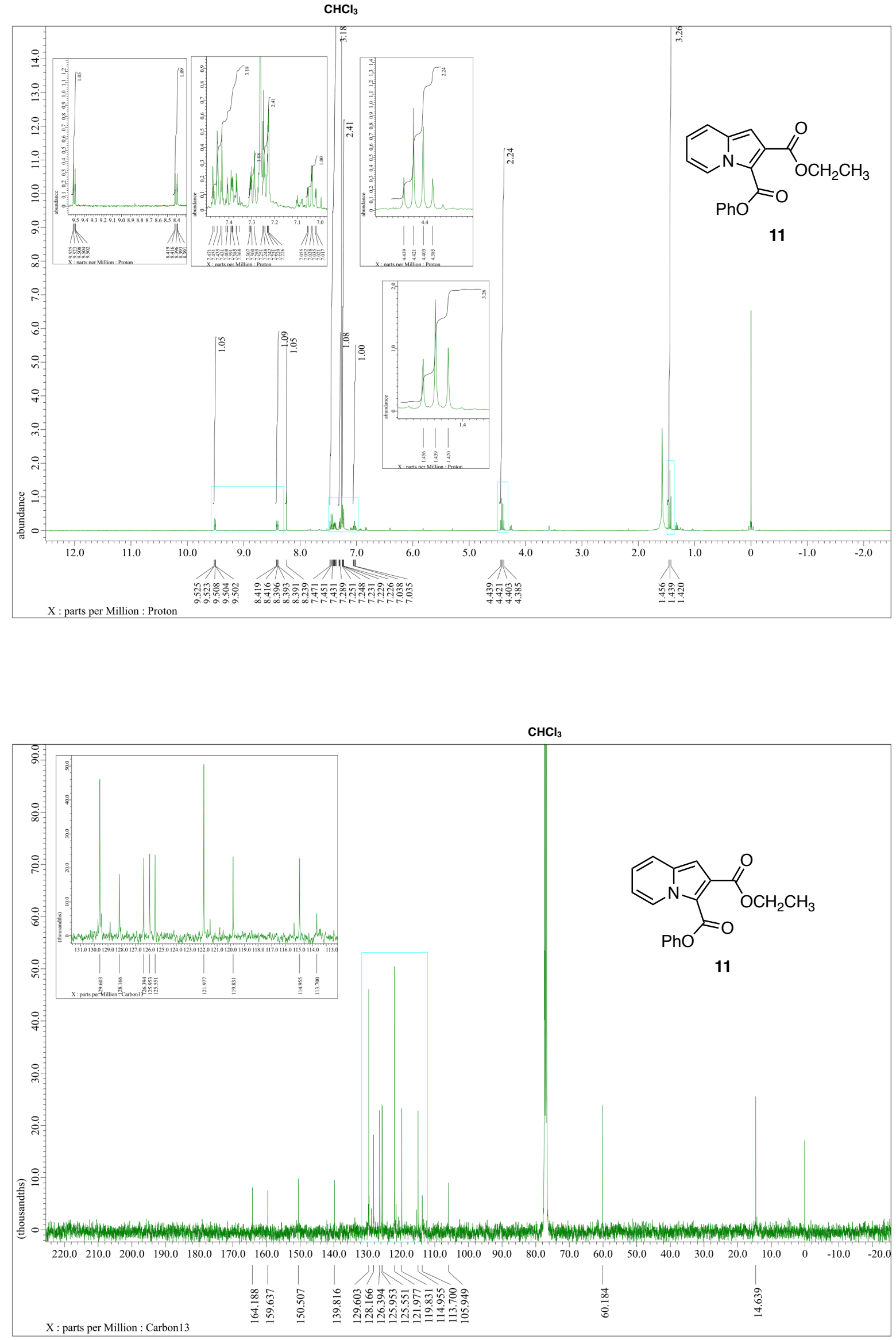
${ }^{1} \mathrm{H}$ NMR (400 MHz) and ${ }^{13} \mathrm{C}$ NMR (100 MHz) spectra of S5 (DMSO- $d_{6}$ )
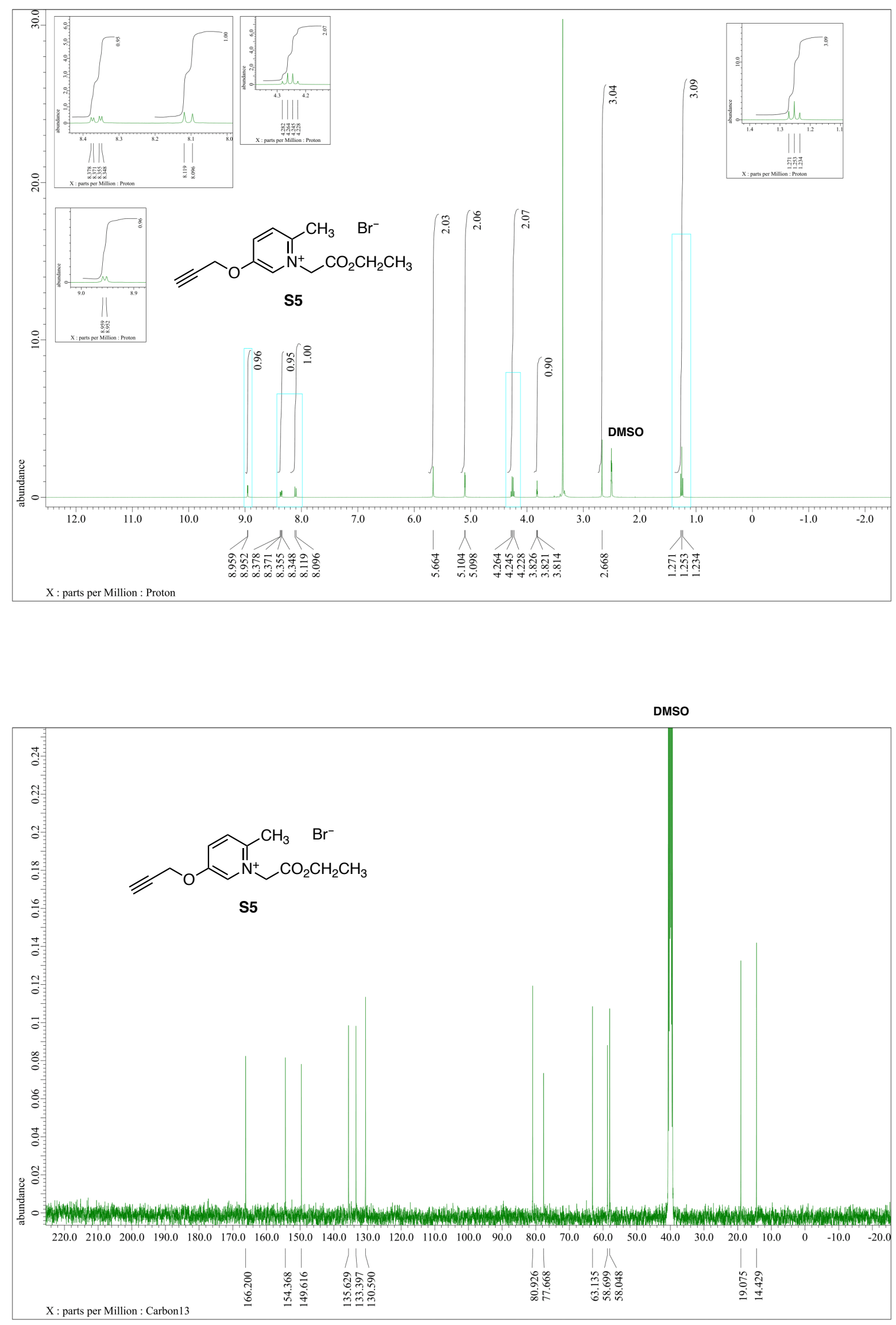
${ }^{1} \mathrm{H}$ NMR $(400 \mathrm{MHz})$ and ${ }^{13} \mathrm{C}$ NMR $(100 \mathrm{MHz})$ spectra of $\mathbf{S 6}\left(\mathrm{CDCl}_{3}\right)$
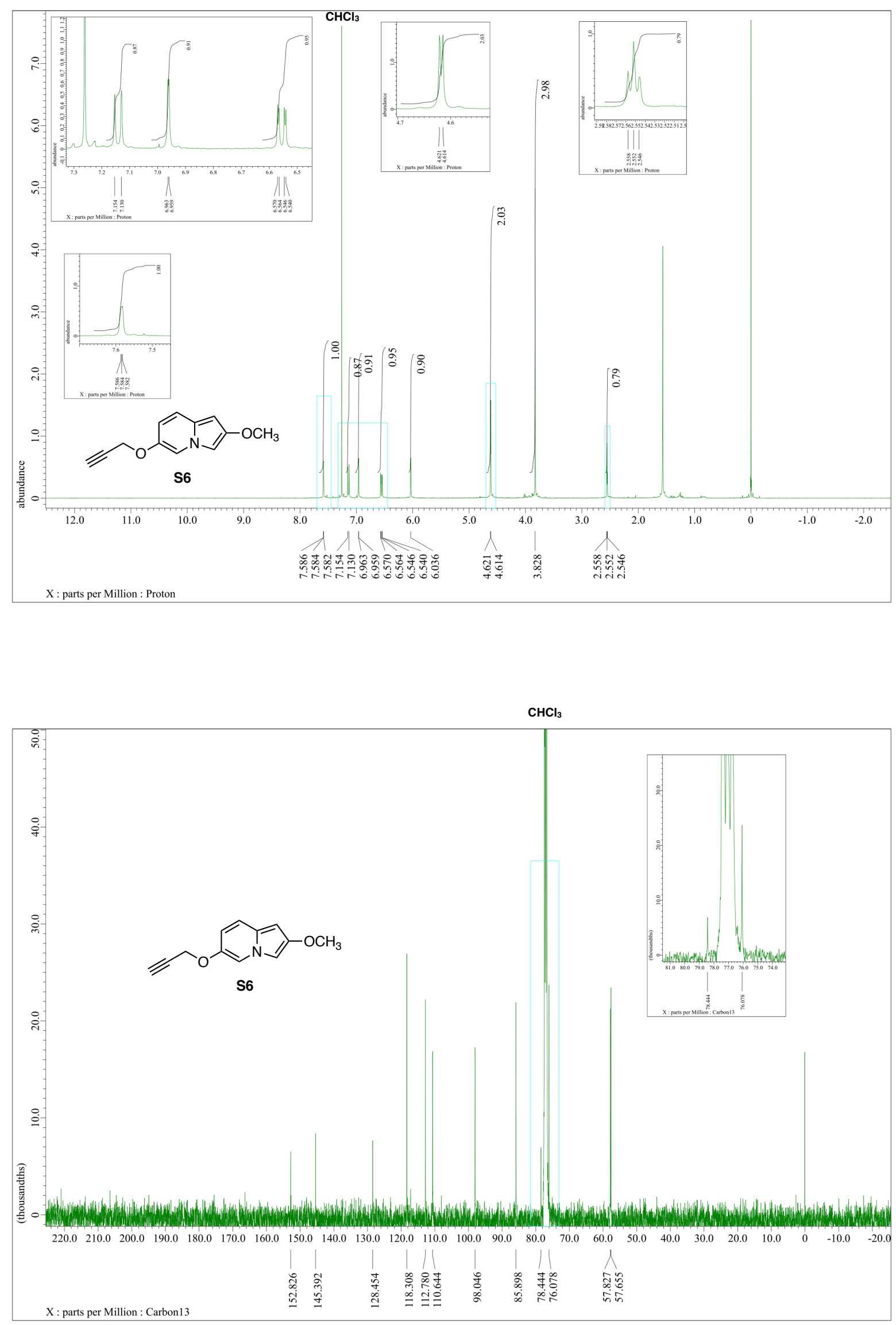
${ }^{1} \mathrm{H}$ NMR (400 MHz) and ${ }^{13} \mathrm{C}$ NMR $(100 \mathrm{MHz})$ spectra of $12\left(\mathrm{CDCl}_{3}\right)$
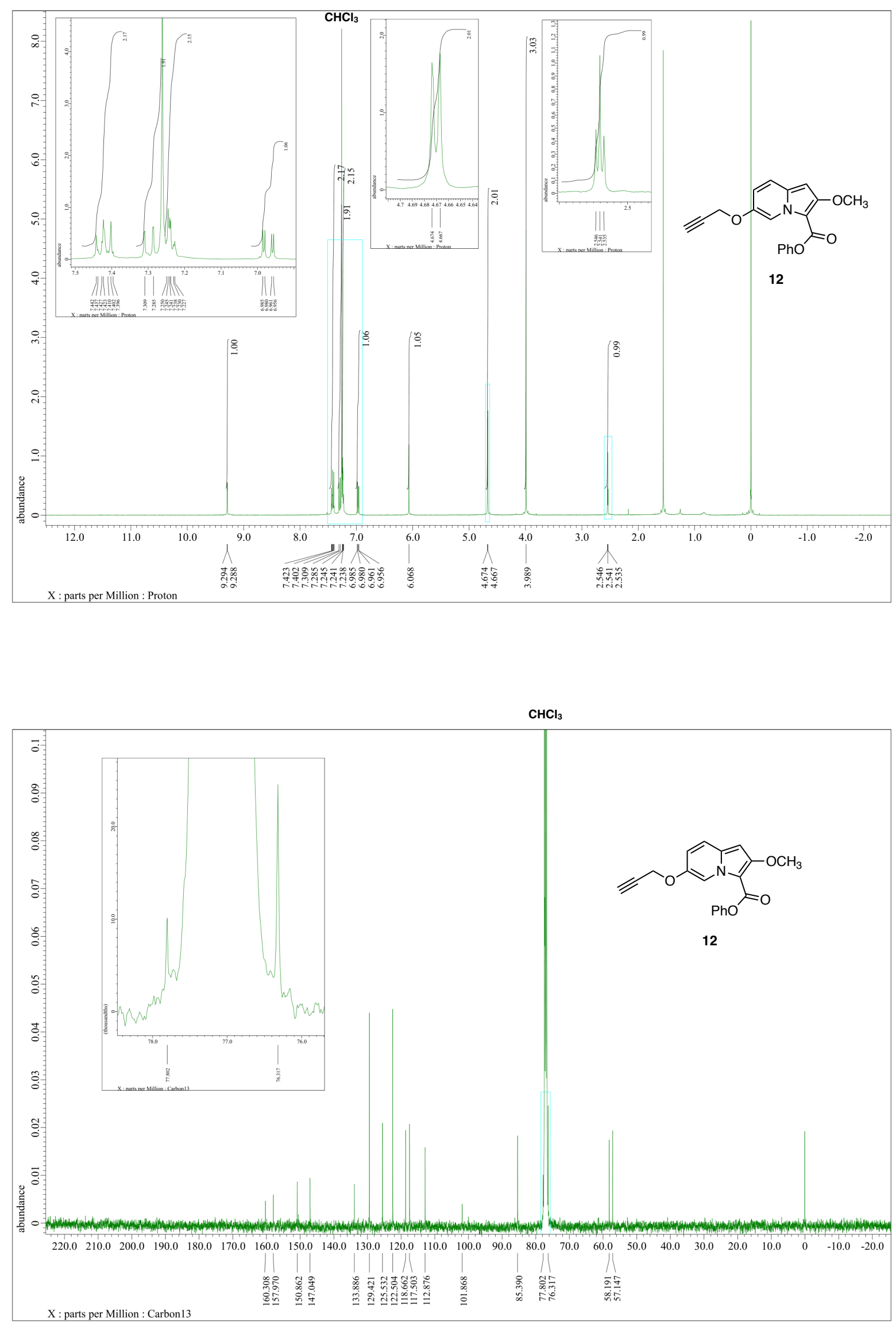
${ }^{1} \mathrm{H}$ NMR (400 MHz) and ${ }^{13} \mathrm{C}$ NMR (100 MHz) spectra of $15\left(\mathrm{CDCl}_{3}\right)$
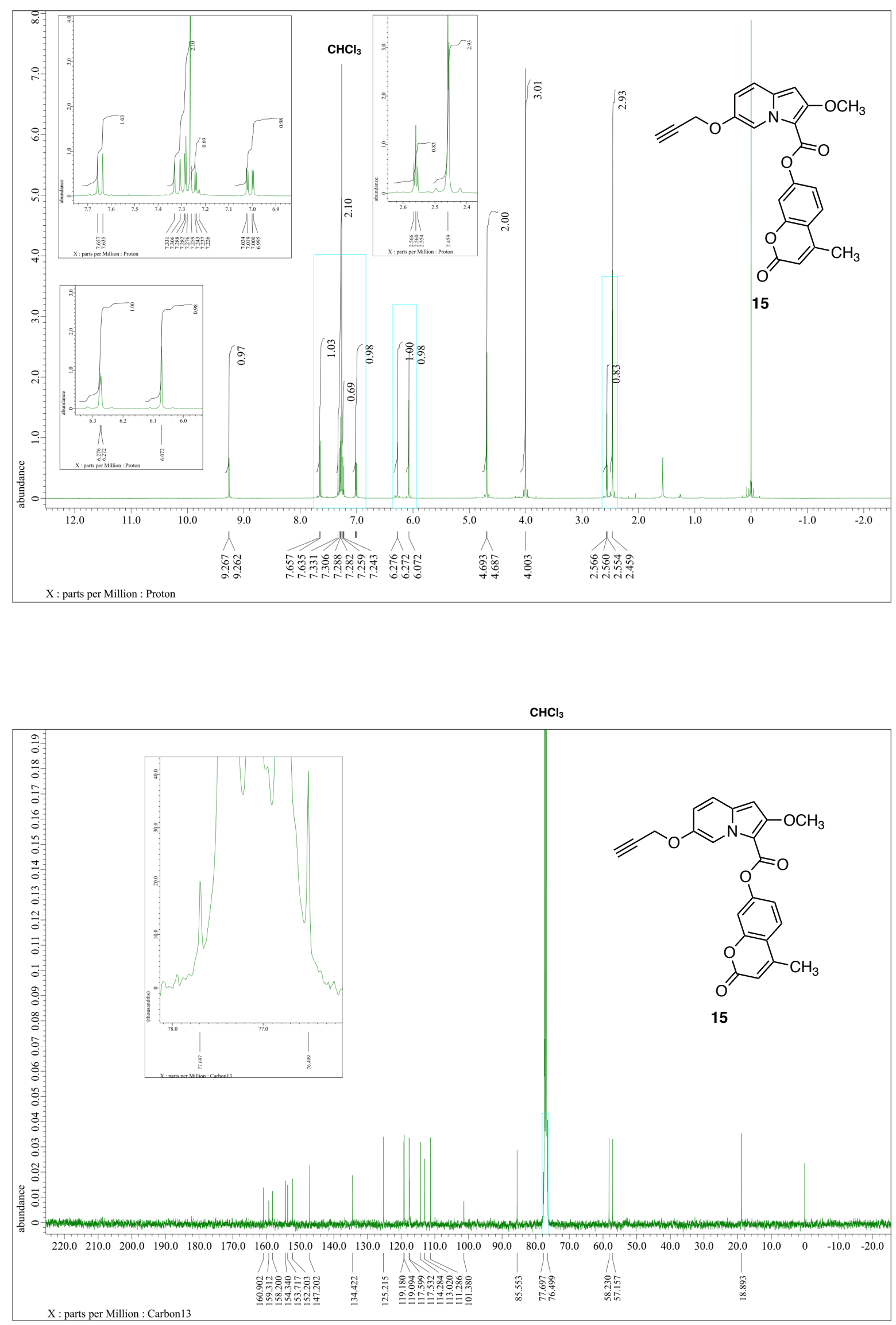
HPLC chart of $\mathbf{1 3}$ (Wavelength of UV detection: $254 \mathrm{~nm}$ )

$=$ Shimadzu Lab Solutions

mAU
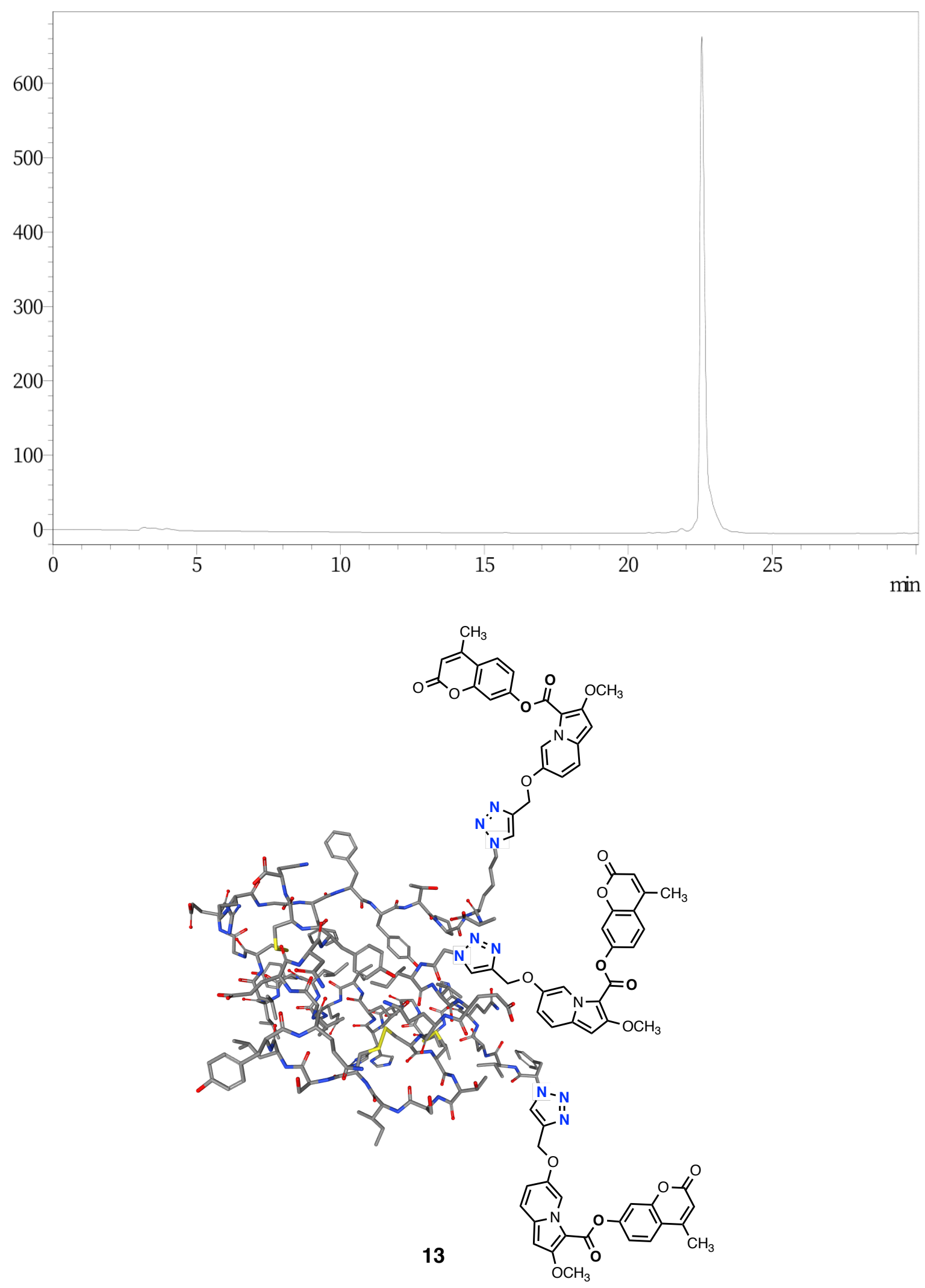